\title{
Gene to Diagnostic: Self immobilizing protein for silica microparticle bi- osensor, modelled with sarcosine oxidase.
}

\author{
Cassi J Henderson ${ }^{\mathrm{a}, \mathrm{b}}$, Elizabeth Pumford ${ }^{\mathrm{a}}$, Dushanth J Seevaratnam ${ }^{\mathrm{a}}$, Ronan Daly ${ }^{\mathrm{b}}$, Elizabeth A \\ $\mathrm{H}$ Halla*
}

${ }^{a}$ Department of Chemical Engineering and Biotechnology, University of Cambridge, Philippa Fawcett Drive, Cambridge, CB3 0AS.

${ }^{b}$ Department of Engineering, University of Cambridge, Charles Babbage Road, Cambridge, CB3 OFS.

\begin{abstract}
A rational design approach is proposed for a multifunctional enzyme reagent for point-of-care diagnostics. The biomaterial reduces downstream isolation steps and eliminates immobilization coupling chemicals for integration in a diagnostic platform. Fusion constructs combined the central functional assay protein (e.g. monomeric sarcosine oxidase, mSOx, horseradish peroxidase, HRP), a visualizing protein (e.g. mCherry) and an in-built immobilization peptide (e.g. R5). Monitoring protein expression in E.coli was facilitated by following the increase in mCherry fluorescence, which could be matched to a color card, indicating when good protein expression has occurred. The R5 peptide (SSKKSGSYSGSKGSKRRIL) provided inbuilt affinity for silica and an immobilization capability for a silica based diagnostic, without requiring additional chemical coupling reagents. Silica particles extracted from beach sand were used to collect protein from crude protein extract with $85-95 \%$ selective uptake. The silica immobilized R5 proteins were stable for more than 2 months at room temperature. The $\mathrm{K}_{\mathrm{m}}$ for the silica-R5 $5_{2}-\mathrm{mCh}-\mathrm{mSOx}-\mathrm{R} 5-6 \mathrm{H}$ was $16.5 \pm 0.9 \mathrm{mM}$ (compared with $16.5 \pm 0.4 \mathrm{mM}, 16.3 \pm 0.3 \mathrm{mM}$, and $16.1 \pm 0.4 \mathrm{mM}$ for R52-mCh$\mathrm{mSOx}-\mathrm{R} 5-6 \mathrm{H}, \mathrm{mSOx}-\mathrm{R} 5-6 \mathrm{H}$ and mSOx-6H respectively in solution). The use of the "silica-enzymes" in sarcosine and peroxide assays was shown, and a design using particle sedimentation through the sample was examined. Using shadowgraphy and particle image velocimetry the particle trajectory through the sample was mapped and an hourglass design with a narrow waist shown to give good control of particle position. The hourglass biosensor was demonstrated for sarcosine assay in the clinically useful range of 2.5 to $10 \mu \mathrm{M}$ in both a dynamic and end point measurement regime.
\end{abstract}

\section{Graphical abstract}

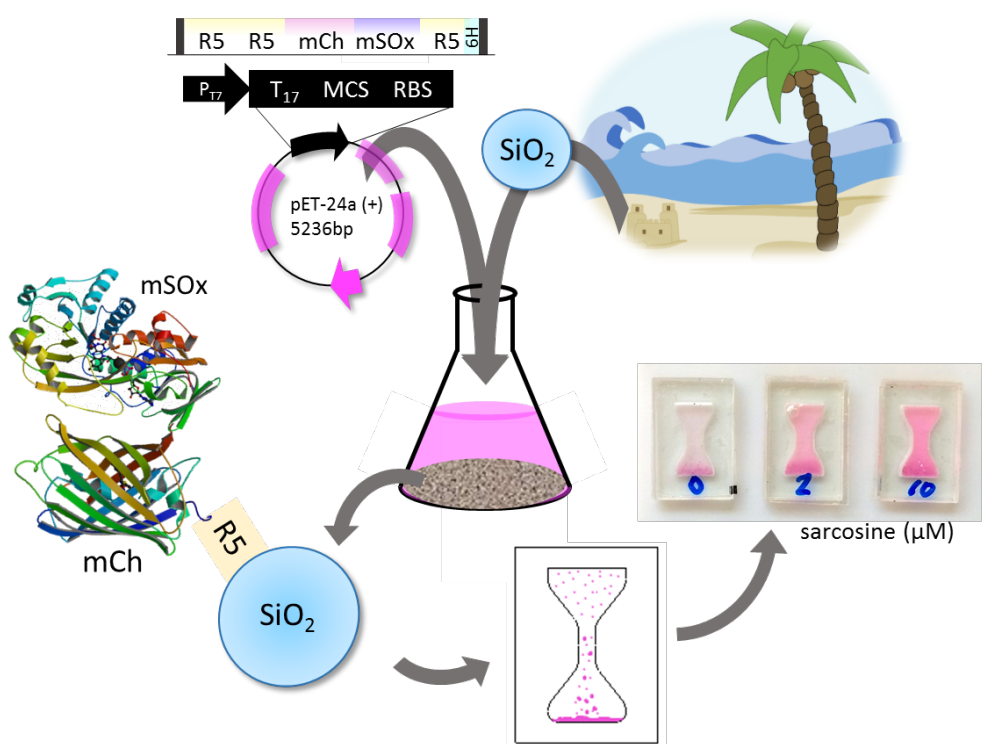

Keywords: biosensors; multifunctional protein; immobilization; protein engineering; sarcosine; silaffin; silica; resource-poor production. 


\section{Introduction}

It has been proposed that low cost in vitro diagnostics (IVD) in clinical practice can, in general, facilitate decisionmaking to guide management of the patient pathway with improved cost effectiveness [1,2]. However, according to a study from Deloitte, $75 \%$ of clinical decisions are based on tests that have to be undertaken in a hospital pathology laboratory. This is too slow to influence the first response in patient treatment [3] and not affordable for resource poor countries.

In low resource areas, the immediate need is often discussed for communicable disease, but chronic non-communicable diseases (CNCD), account for more than half the burden of disease and the greatest global share of death and disability, affecting people of all ages, nationalities and classes. It is estimated that two thirds of cancer cases will emerge in low and middle income countries (LMICs) by the end of the next decade $[4,5]$. Unfortunately, early diagnosis programs are not affordable in this context. Currently, IVDs typically only include assays like blood glucose and cholesterol and they are especially challenging to afford and integrate into LMICs [6].

Lack of beneficial monitoring in the management of diabetes for example, is one of the biggest contrasts with high income countries. In Mozambique only $6 \%$ of facilities could carry out a blood glucose analysis and personal monitoring is not available in general [7]. Yet, the high prevalence of diabetes in LMICs is not accounted for by conventional risk factors including body mass index (BMI) [8] and an increasing number of the populations are contracting type 2 diabetes at a younger age [9]. Monitoring is beyond their financial reach and is thus an impediment for surveillance and clinical management.

There have been numerous attempts to propose low cost diagnostics for LMICs, but they remain at high cost when taken in the local context. Social innovation studies emphasize the need to improve society's capacity to solve their own problems [10]. Innovation is therefore required to empower low income countries, through local production, without subsidies or major infrastructure investment [11-13]. However, the required biological materials for a point of care diagnostic can be the largest proportion of the total cost for the device (e.g. $>80 \%$ in the Philippines, at nearly the same cost price as in US and Europe, despite the average household income being $80-90 \%$ lower).

Pursuance of paper diagnostics $[14,15]$ and use of other low cost manufacturable substrates has been studied as an approach to affordable medical diagnostics in limited resource settings [16]. The 'plastic-free' biodegradable movement will further encourage the use of plant based materials and the sourcing of naturally occurring renewables (e.g. zein [17]) and other readily available materials. Silica is an example of such a low cost available material that can be easily modified chemically, to present different external functional pendant groups, allowing tethering of biological molecules and other components [18,19]. Silica based sol-gel materials have provided an immobilization encapsulant [20], offering useful biocompatibility for biosensors, with retention of activity of immobilized biomolecules and integration with various transduction techniques [21].
Surface modification of the substrate is one of the key objectives in biosensor design to unite the biorecognition chemistry with the measurement system and integrate the core analytical reagent [22]. This could be replaced by posttranslational addition of specific peptides [23,24]. Nevertheless, taking a synthetic biology approach to the biorecognition reagent, suggests that a modular synthetic protein design, able to perform the tasks of both biorecognition and immobilization could eliminate a number of steps in the production pathway. This could reduce the use (and cost) of chemical reagents and processing steps. Furthermore, such modular protein design allows other potentially cost saving or optimizing functionality to be included. In the research reported herein, we propose a multiprotein-complex design, to achieve these aims. A fusion protein construct is explored that combines A) the central functional assay protein (e.g. enzyme); B) a visualizing protein (e.g. fluorescent protein) to provide a reference measurement in the final diagnostic and facilitating visual monitoring of the production and isolation without a laboratory infrastructure; C) an in-built immobilization peptide which is fundamental to stabilization and effective interfacing with (i) the sample (ii) the diagnostic platform and importantly (iii) plays a key role in simplifying isolation and purification. Depending on the choice of peptide, different platform substrate materials can be chosen (e.g. paper, silica, metals, carbon etc.). This initial study will focus on silica as the core low cost abundantly available material. It takes a 'gene to diagnostic' approach to materials that can be expressed in vivo in $E$. coli with one step purification and silica biosensor integration.

In this preliminary demonstration, the enzyme sarcosine oxidase is explored as a first model. Sarcosine levels have been studied in urine as a marker of early-stage prostate cancer, when its level rises over $5 \mu \mathrm{M}[25,26]$. Interest in sarcosine as a biomarker for prostate cancer is stimulating ideas for IVDs and with access to diagnostics unaffordable in vulnerable LMICs, there is a need to consider a different approach that doesn't presume the use of expensive off-theshelf reagents.

Taking inspiration from "Garage Biotech", which has captured the interest of the hobbyists and enabled the DIY scientist to produce proteins with no conventional laboratory resources [27], we report on the first steps to demonstrate the principle of "gene to device", short-circuiting downstream processing and immobilization steps and showing that the silica material focus can open up new directions for diagnostic platform design.

\section{Materials and Methods}

Materials sourced from Sigma-Aldrich: sarcosine, horse radish peroxidase (HRP), isopropyl $\beta$-D-1-thiogalactopyranoside (IPTG), sodium chloride $(\mathrm{NaCl})$, sodium phosphate dibasic $\left(\mathrm{Na}_{2} \mathrm{HPO}_{4}\right)$, potassium phosphate monobasic $\left(\mathrm{KH}_{2} \mathrm{PO}_{4}\right)$, sodium hydroxide $(\mathrm{NaOH})$, lysozyme (from chicken egg white), TritonX-100, sulfuric acid $\left(\mathrm{H}_{2} \mathrm{SO}_{4}\right.$ 95\%), bovine serum albumin (BSA), 2,2'-azino-bis(3ethylbenzothiazoline-6-sulphonic acid) (ABTS), Coomaisse Brilliant Blue, phosphoric acid, L-ascorbic acid, glucose, glycine, silica gel $150250-500 \mu \mathrm{m}$, benzonase nuclease, imidazole, 2-mercaptoethanol, calcium chloride $\left(\mathrm{CaCl}_{2}\right)$. Ma- 
terials sourced from Invitrogen: Amplex UltraRed. Materials sourced from Melford Laboratories: LB Agar (L1706), LB Broth (L1704), Kanamycin (K0126), carbenicillin. Materials source from Acros Organics: potassium chloride $(\mathrm{KCl})$, uric acid, L-alanine, L-proline, creatinine. Materials sourced from alternate suppliers: commercial silica gel 60 $(<63 \mu \mathrm{m} / \mathrm{mesh}<230$ (Fluka), 6-35 $\mu \mathrm{m}$ (Fisher Scientific), 40-

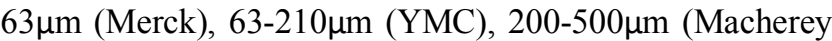
Nagel)), polymethylmethacrylate (PMMA, Engineering and Design Plastics), glycerol (Fisher Scientific), hydrogen peroxide $\left(30 \% \mathrm{w} / \mathrm{v}\right.$ in $\mathrm{H}_{2} \mathrm{O}$, Fisher Bioreagents), dopamine salt (LKT laboratories Inc.), N-methyl-L-alanine (Alfa Asear), 5-aminolevulinic acid (Cayman Chemical Company).

\subsection{Protein design and expression for $\mathrm{R} 55_{5}-\mathrm{mCh}-6 \mathrm{H}, \mathrm{R} 5_{2}-$ $m$ Ch-mSox-R5-6H}

E.coli glycerol stock with mCherry-6H, mCherry-R5$6 \mathrm{H}$, and $\mathrm{R} 55-\mathrm{mCherry}-6 \mathrm{H}$ constructs in pET24a expression vector were prepared previously in house. Chemically competent NovaBlue Singles E.coli cells (endA1 hsdR17 ( $\left.\mathrm{r}_{\mathrm{K} 12}{ }^{-} \mathrm{m}_{\mathrm{K} 12}{ }^{+}\right)$supE44 thi-1 recAl gyrA96 relA1 lacF' $\left[\right.$ proA $\left.\left.^{+} B^{+} l a c I^{q} Z \Delta M 15:: \operatorname{Tn} 10\right]\left(\mathrm{Tet}^{\mathrm{R}}\right)\right)$ were used for transformation and plasmid propagation. pET24a was used as the expression vector.

The original $\mathrm{mSOx}$ sequence was ordered from Gene$\mathrm{Art}^{\mathrm{TM}}$ Gene Synthesis. For mSOx, the genes were cloned into pET24a plasmids previously available in house. The pET24a vector encoding mSOx-R5 was used as a template for $\mathrm{R} 52$-mCherry-mSOx-R5 fusion protein construction. The vector was subjected to site directed mutagenesis aimed to add two restriction sites of NdeI and BamHI for insertion of the mSOx-R5 gene, while the stop codon was placed at the end of the sequence.

\subsection{Protein design and expression for HRP-mCh-R5-6H and 6H-R5-mCh-HRP}

The HRP sequences were ordered from GeneArt ${ }^{\mathrm{TM}}$ Gene Synthesis. The genes were cloned into pAK plasmid. The constructs were assembled in NEB Turbo cells using the Klenow Assembly Method. PCR, transformation and DNA sequencing were completed as aforementioned (Supporting Information, Experimental).

\subsection{Protein purification, all constructs}

Protein purification was performed using Nickel HisBind Resin (Novagen). The purification columns were prepared as recommended by the manufacturer. The column was first washed by $5 \mathrm{x}$ bed volume of equilibration buffer (20 mM sodium phosphate, $500 \mathrm{mM} \mathrm{NaCl}, 20 \mathrm{mM}$ imidazole, $\mathrm{pH}$ 7.8), followed by loading the supernatant of the cell suspension. The impurities were removed by washing with $3 \mathrm{x}$ bed volume of binding buffer (buffer A with $20 \mathrm{mM}$ imidazole), $5 x$ bed volume of wash buffer (buffer A with 50 $\mathrm{mM}$ imidazole). The target protein was then eluted with $5 \mathrm{x}$ bed volume of elution buffer (buffer A with $250 \mathrm{mM}$ imidazole).

The purified proteins were confirmed using size analyses of denatured proteins on sodium dodecyl sulfate polyacryla- mide gel electrophoresis (SDS-PAGE, 8\% SDS). The presence of the R5-silaffin tag was confirmed by protein sequencing using LC-MS (Table S4). The yield for R55-mCh$6 \mathrm{H}$ is $200 \mathrm{mg} / \mathrm{L}$ culture, for $\mathrm{R} 52-\mathrm{mCh}-\mathrm{mSox}-\mathrm{R} 5-6 \mathrm{H}$ is $220 \mathrm{mg} / \mathrm{L}$, for HRP-mCh-R5-6H is $6 \mathrm{mg} / \mathrm{L}$ and for $6 \mathrm{H}-\mathrm{R} 5-$ $\mathrm{mCh}-\mathrm{HRP}$ is $3 \mathrm{mg} / \mathrm{L}$ after Ni-purification.

\subsection{Extraction of $\mathrm{SiO}_{2}$ from sand}

The protocol followed previously published methods with some changes [28,29] (Fig. S1). Using small amounts of sand $(<5 \mathrm{~g})$ the sand and crushed $\mathrm{NaOH}$ was combined and the mixture was transferred into a Pyrex assay tube and heated over a flame for 3-5 min. After cooling, water was added and it was filtered through filter paper QL100 (Fisherbrand). $\mathrm{H}_{2} \mathrm{SO}_{4}(95 \% 0.25-1 \mathrm{~mL})$ was added carefully, drop by drop, to the filtered solution. The white precipitate was collected, centrifuged (13k rpm for $1 \mathrm{~min}$ ) and washed with water several times $(1 \mathrm{~mL}, 3 \mathrm{X})$. The white precipitate was dried at room temperature for 5+ days. Original sands and dried precipitate were analyzed by FTIR (SpectrumOne, Perkin Elmer) and imaged by light microscopy. The surface area was calculated by Brunauer-Emmett-Teller (BET) surface area analysis (Quantachrome Instruments), $\sim 100 \mathrm{mg}$ tested.

\subsection{Immobilisation of the R5-proteins on silica particles}

A suspension of silica particles $(10 \mathrm{mg} / \mathrm{mL}, 5 \mathrm{mg}$ in $0.5 \mathrm{~mL})$ was prepared in buffered saline $\left(100 \mathrm{mM} \mathrm{Na}_{2} \mathrm{HPO}_{4}\right.$, $150 \mathrm{mM} \mathrm{NaCl}, \mathrm{pH} 7.5)$. The mixture was sonicated for $1 \mathrm{~h}$ (water bath FB15056, Fisher Scientific), and a volume of either purified protein (R5-mCh-6H, HRP-mCh-R5-6H) or crude lysate ( $\left.\mathrm{R}_{2}-\mathrm{mCh}-\mathrm{mSOx}-\mathrm{R} 5-6 \mathrm{H}\right)$ was added. The final concentration of the protein was between $0.05-0.5 \mathrm{mg} / \mathrm{mL}$. After mixing by vortex (VariMix, SciEquip), the suspension was rotated (SB1 tube rotator, Stuart Science) for $1 \mathrm{~h}$ and left at room temperature to precipitate. The particles became pink and the supernatant colorless. The protein modified silica was centrifuged at $13 \mathrm{k} \mathrm{rpm}$ for $5 \mathrm{~min}$. The percentage of R5-protein immobilized was calculated by measuring the fluorescence intensity characteristic of mCherry, i.e. ex/em 587/607nm (Cary Eclipse Fluorescence Spectrophotometer, Varian) of the free protein in supernatant at the beginning and end of the immobilization.

Absorbance (Infinite M200, Tecan) and fluorescence readings were taken of both particles and free proteins in solution. The particles were washed several times with water and no leaching of the protein from the particles to the solution was observed, as measured by fluorescence. Confocal microscopy images were obtained using Leica TCS SP2 spectral confocal microscopy.

A Bradford assay was used to determine the total protein immobilization. In brief, $20 \mu \mathrm{L}$ of supernatant following the first spin-down after incubation was added to $100 \mu \mathrm{L}$ Bradford reagent (Coomassie Brilliant Blue in phosphoric acid) in a well plate and absorbance at $595 \mathrm{~nm}$ was measured with a UV spectrophotometer and compared with a standard curve made with BSA.

Elution of the proteins off silica was achieved by incubation in $0.5-1 \mathrm{M}$ lysine for $30-120 \mathrm{~min}$. 


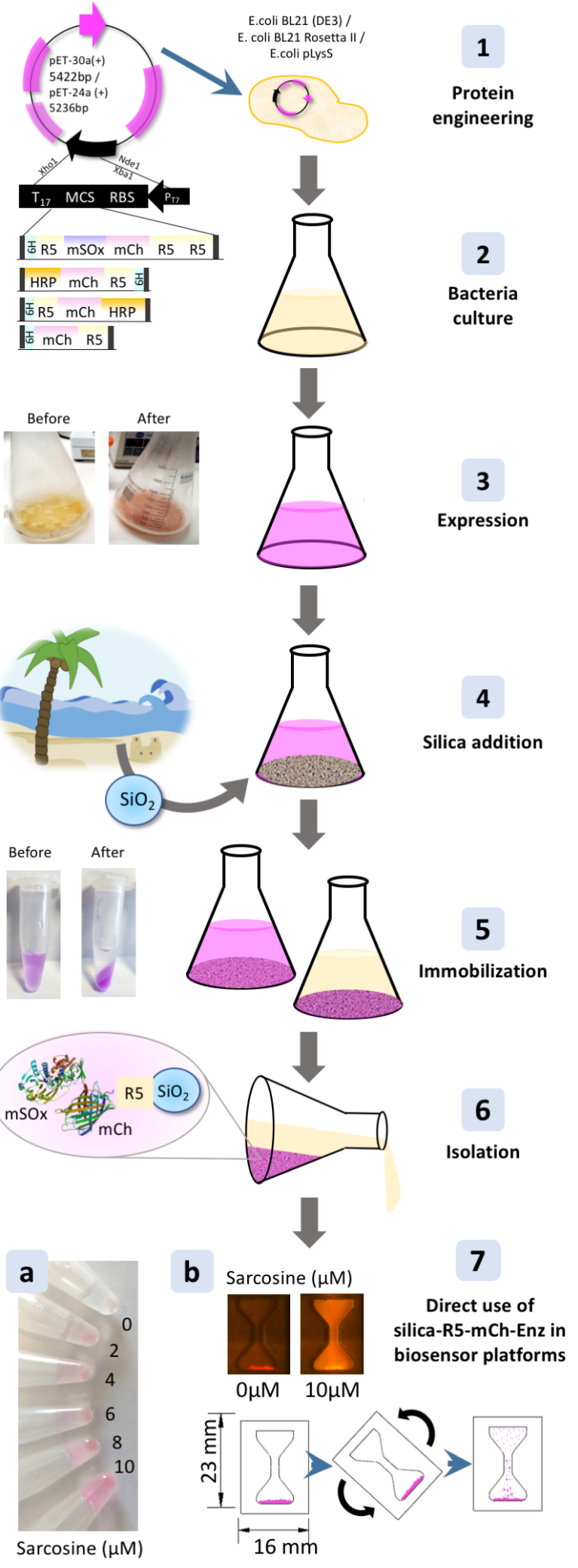

Fig. 1. Schematic illustration of the "gene to device" pathway; 1) Protein engineering to obtain R5-mCh-Enz, 2) Bacterial culture growth, 3) Protein expression, 4) Addition of silica (extracted from sand) to crude lysate, 5) Protein purification/ immobilization/stabilization on silica, before and after examples in microcentrifuge tubes shown, 6) Isolation of silica-R5$\mathrm{mCh}-\mathrm{Enz}, 7)$ Direct use of the silica-R5-mCh-Enz in biosensor platforms, as shown by silica-R $5_{2}-\mathrm{mCh}-\mathrm{mSOx}-\mathrm{R} 5-6 \mathrm{H}$ for the detection of sarcosine. The silica-R5-mCh-Enz particles can be used in 7a) a classical solution based assay or 7b) in a novel hourglass biosensor design. (mCh structure 2HQ5 and mSOx 3QSE from RCSB Protein Data Bank).

\subsection{Determination of sarcosine and $\mathrm{H}_{2} \mathrm{O}_{2}$}

Sarcosine or $\mathrm{H}_{2} \mathrm{O}_{2}$ was detected by a combination of functional R5 proteins (R52-mCh-mSOx-R5-6H and/or HRP-mCh-R5-6H or 6H-R5-mCH-HRP, respectively) and the dye Amplex UltraRed (AR) for both free and immobilized protein.

For the detection of sarcosine in well plates with free protein, $10 \mu \mathrm{L}$ of purified $\mathrm{R} 55_{2}-\mathrm{mCh}-\mathrm{mSOx}-\mathrm{R} 5-6 \mathrm{H}$ $(1.9 \mathrm{mg} / \mathrm{mL})$ was added to $0-10 \mu \mathrm{L}$ volumes of sarcosine solution $(100 \mu \mathrm{M}), 10 \mu \mathrm{L}$ of $\mathrm{HRP}(0.4 \mathrm{mg} / \mathrm{mL})$ and $10 \mu \mathrm{L}$ of AR $(1 \mathrm{mM})$. For the detection of $\mathrm{H}_{2} \mathrm{O}_{2}, 40 \mu \mathrm{L}$ of purified HRP-mCh-R5-6H $(0.12 \mathrm{mg} / \mathrm{mL})$ was added to $0-20 \mu \mathrm{L}$ of $841 \mu \mathrm{M} \mathrm{H}_{2} \mathrm{O}_{2}$ and $10 \mu \mathrm{L}$ of $\mathrm{AR}(1 \mathrm{mM})$. The final volume in each well was adjusted to $100 \mu \mathrm{L}$ with water. The fluorescence was measured, after reaction for $20 \mathrm{~min}$ at room temperature (in the dark), at ex/em 530/582 nm, PMT voltage $800 \mathrm{~V}$, excitation slit $5 \mathrm{~nm}$. Emission slit was $10 \mathrm{~nm}$ for $\mathrm{mSOx}, 5 \mathrm{~nm}$ for HRP. The increase in fluorescence intensity of substrate standard (I) with respect to the blank ( $\left.\mathrm{I}_{0}\right)$ was plotted against the concentration of substrate (sarcosine or $\mathrm{H}_{2} \mathrm{O}_{2}$ ). Selectivity and $\mathrm{pH}$ effect were evaluated with a similar protocol (Supporting information, Experimental).

For each size and pore class of commercial silica particles, detection of $10 \mu \mathrm{M}$ sarcosine was compared using the Amplex UltraRed assay as described above. The quantity of silica added was adjusted based on immobilization efficiency in order to maintain equivalent enzyme concentration. For experiments comparing particle size and pore size, the microcentrifuge tubes were rotated for 40 or 60 minutes, respectively, before fluorescence was measured.

Endpoint assays for sarcosine were done in well plates, $50 \mu \mathrm{L}$ each assay with $50 \mu \mathrm{M}$ Amplex UltraRed, $0.04 \mathrm{mg} / \mathrm{mL}$ HRP, $3.75 \mathrm{mg}$ Si-R5 2 -mCh-mSOx-R5-6H and various final concentrations of sarcosine.

Trinder's colorimetric assay was adapted to measure specific activity of sarcosine oxidase and specific activity for HRP constructs was measured using a colorimetric assay with ABTS (Supporting information, Experimental).

\subsection{Hourglass biosensor construction and use}

Hourglass sensors were produced by laser cutting the shape from $2 \mathrm{~mm}$ thick PMMA and sealing both sides with PCR plate seal (Thermo Scientific Adhesive PCR Plate Seal). Total volumes were 200/240/320 $\mu$ L for the narrow / standard /parallel-sided design respectively (Fig. S6). For the detection of sarcosine, R52-mCh-mSox-R5-6H immobilized on silica extracted from sand $(4.17 \mathrm{mg} / \mathrm{mL}$ silica, $0.19 \mathrm{mg}$ protein per $1 \mathrm{mg}$ silica) was mixed with AR (4.17 $\mu \mathrm{M}), \mathrm{HRP}(0.016 \mathrm{mg} / \mathrm{mL})$ and sarcosine $(0 \mu \mathrm{M}$ (blank), 2 , $4,6,8 \mu \mathrm{M})$ ) and loaded into the device. For the detection of $\mathrm{H}_{2} \mathrm{O}_{2}$, HRP-mCh-R5-6H was immobilized on silica extracted from sand $(2.7 \mathrm{mg} / \mathrm{mL}$ silica, $0.025 \mathrm{mg}$ protein per $1 \mathrm{mg}$ silica) was mixed with $\mathrm{AR}(10.8 \mu \mathrm{M})$ and $\mathrm{H}_{2} \mathrm{O}_{2}(0 \mu \mathrm{M}$ (blank), 21, 42, 84, $126 \mu \mathrm{M})$ ) and loaded into the device. All concentrations reported are final concentrations in the assay. 
The sealed device containing the sarcosine or $\mathrm{H}_{2} \mathrm{O}_{2}$ sample, was inverted for mixing as described in the text, each time allowing the particles to settle to the bottom (60s). After settling, the device was laid on an FFEI reader (505nm LED for excitation and a CCD RGB linear sensor for detection) and fluorescence intensity was recorded. The images were analyzed for grey scale intensity of the red channel in the detection area using ImageJ software. An intensity profile was extracted along a central line perpendicular to the base and the change in area under the curve (AUC) over time recorded or the average intensity at the endpoint $(7 \mathrm{~min})$ was plotted against concentration.

\subsection{Particle Shadowgraphy and PIV analysis}

Particle settling was observed using a shadowgraphy technique. For illumination, a $100 \mathrm{~W}$ light-emitting diode (LED) array with a light diffuser was placed behind the 'device' and aligned to the camera. The resulting shadow was captured by a highspeed camera (Phantom v130) with a $12 \mathrm{X}$ lens and accessories (Navitar). Videos were captured at $50 \mathrm{fps}$. Fixtures were designed to hold the device and to allow rotation in plane or about a horizontal axis through the middle of the device (flip). Devices were filled with $5 \mathrm{mg} / \mathrm{mL}$ extracted silica immobilized with $\mathrm{R} 52-\mathrm{mCh}-\mathrm{mSox}-\mathrm{R} 5-6 \mathrm{H}$ suspended in $\mathrm{H}_{2} \mathrm{O}$ and sealed. Frames from the video were converted to grayscale (rgb2gray) and color inverted (imcomplement) using MATLAB.

Particle image velocimetry (PIV) analysis was performed using PIVLab app in MATLAB, using FFT window deformation and four successive passes of pixel area 64,32 , 16 and 8, with $50 \%$ step overlap, for each pair of images. Image overlays were done in ImageJ using Z-projections of maximum pixel value for grayscale inverted video frames imparted into virtual stacks.

In sedimentation modelling, a density of $2.18 \mathrm{~g} / \mathrm{cm}^{3}$ was used with corresponding Pe numbers, based on the calculated matching velocities using particle diameter as characteristic length. For Pe, mass diffusivity of glycine was used as approximation for sarcosine.

\section{Results and Discussion}

\subsection{Protein architecture and expression}

The rationale explored in this work builds on the use of silica as a low cost substrate in a biosensor design. It considers a protein architecture that will integrate the assay reagent enzyme with silica via a silaffin (silica affinity) peptide, without additional chemical reagents or immobilization steps, but with retention of enzyme activity and increased enzyme stability. The enzymatic assay for sarcosine usually employs the enzyme sarcosine oxidase (SOx) coupled with horseradish peroxidase (HRP). By designing these reagents through recombinant protein technology, additional functionality can be incorporated in the protein that will fit them more ideally for a diagnostic platform use. Here, we incorporate the fluorescent protein mCherry $(\mathrm{mCh})$ to provide a visual marker of protein production and isolation success with minimal laboratory infrastructure.

To demonstrate this protein architecture, we have designed plasmids that incorporate the silaffin (silica affinity) (a)

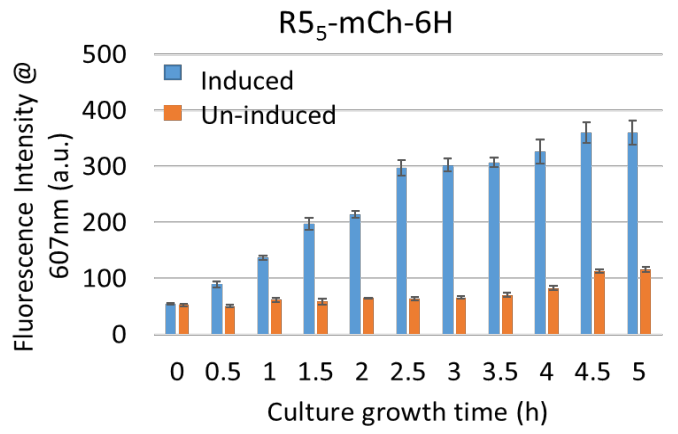

(b)

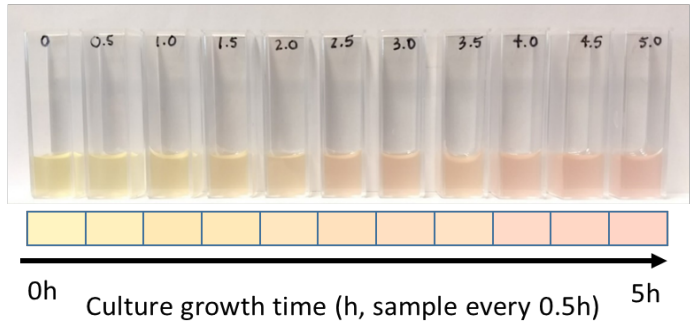

(c)

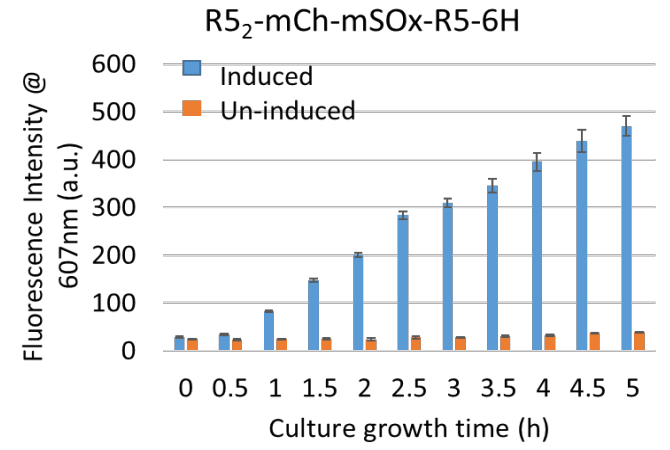

(d)

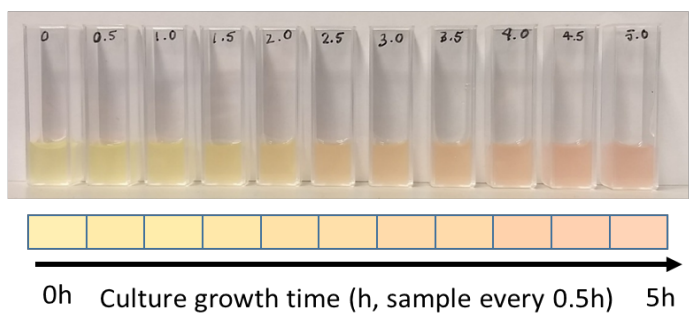

(e)

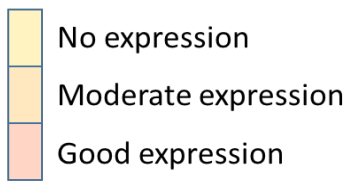

Fig. 2. Fluorescence intensity at $\lambda \mathrm{em} / \mathrm{ex} 607 / 587 \mathrm{~nm}$ for (blue) induced and (orange) un-induced culture over growth period for (a) $\mathrm{R} 55-\mathrm{mCh}-6 \mathrm{H}$ and (c) $\mathrm{R} 55_{2}-\mathrm{mCh}-\mathrm{mSOx}-\mathrm{R} 5-6 \mathrm{H}$, and corresponding cuvette samples (b and d) to show visual change in color. Expression levels can be checked semi-quantitatively against a color card (e).

peptide (R5)[30] and mCherry ( $\mathrm{mCh}$ ) fluorescent protein together with monomeric sarcosine oxidase (mSOx). A construct with $\mathrm{mSOx}$ was designed (R52-mCh-mSOx-R5-6H) for expression in E.coli (Fig. 1, step 1). The inclusion of mCherry in an indicator role is immediately evident during the production step: for example, expression of the $\mathrm{R} 5_{2}-$ mCh-mSOx-R5-6H in E.coli produces a pink culture, showing that protein expression has occurred ( 5 h, Fig. 1, step 2 to 3 ) and the protein is ready for collection (Fig. 2). The in- 

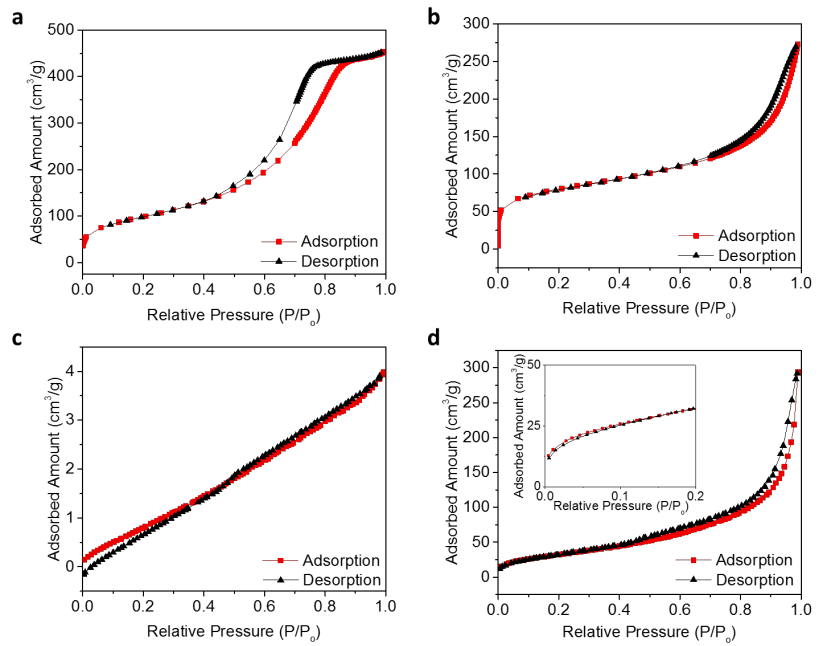

Fig. 3. $\mathrm{N}_{2}$ isotherms for silicas. (a) commercial silica (b) silica extracted from sand (USA) (c) sand (USA) and (d) silica extracted from sand (USA) immobilized with $\mathrm{R} 52_{2}-\mathrm{mCh}-\mathrm{mSOx}-\mathrm{R} 5-6 \mathrm{H}$.

crease in the inbuilt fusion protein fluorescence, as a function of protein expression after induction, is demonstrated for two $\mathrm{R} 5$ protein constructs with and without $\mathrm{mSOx}$ (R55$\mathrm{mCh}-6 \mathrm{H}$ and $\mathrm{R} 52_{2}-\mathrm{mCh}-\mathrm{mSOx}-\mathrm{R} 5-6 \mathrm{H}$ ), having slightly different growth curves (Fig. 2). It can also be followed semiquantitatively (visual color matching - Fig. $2 b$ and d) or checked against a color card (Fig. 2e), depending on available resources.

This combined immobilization and visualization functionality, which would normally be fulfilled through separate materials and/or equipment, could reduce production steps and facilitate an integrated pathway from raw material to end diagnostic.

\subsection{Silica integration}

Silica is an enormously abundant indigenous material; e.g. it is the main component from beach sand and can be extracted easily $[28,29]$ (Fig. S1) and used directly without size selection (see Fig. 5a for particle size distribution for the material used in this work). The FTIR spectra of the silica extracted from beach sand show characteristic symmetric and asymmetric stretching modes for Si-O-Si $\left(804-805 \mathrm{~cm}^{-}\right.$ ${ }^{1}$ and $1079-1088 \mathrm{~cm}^{-1}$ respectively) and the asymmetric Si$\mathrm{OH}$ mode $\left(952-953 \mathrm{~cm}^{-1}\right)$, which overlay with silica gel (Fig. S1d).

Despite this similarity, the $\mathrm{N}_{2}$ gas adsorption/desorption isotherms (Fig. 3) suggest that the silica precipitated from sand-processing is nonporous or macroporous ( $>50 \mathrm{~nm})$ and undergoes a nearly reversible multilayer adsorption (type II isotherm). In contrast the commercial silica gel (60 A pore diameter) demonstrates mesoporous (type IV isotherm) behavior, which is typical of monolayer/multilayer adsorption followed by capillary condensation in the mesopores. This is also consistent with the higher density for sand-silica than commercial silica gel (Table 1). Fig. $3 \mathrm{c}$ also shows that $\mathrm{N}_{2}$ adsorption on crude sand is very low (negligible adsorption of the R5 protein is also found on crude sand).

Comparison of Fig. 3b and 3d identifies the effect of R5protein adsorption on the silica. The minor hysteresis seen in Fig. 3d shifts to a lower relative pressure consistent with decreasing pore diameter. The characteristic 'step down' in the desorption curve, closing the hysteresis loop is usually associated with pore blocking and percolation effects and the lower step down relative pressure would be consistent with the protein covering on the silica surface contributing to this blocking. These differences are supported by comparison of BET surface areas and, in particular, $>50 \%$ reduction in surface area following protein adsorption (Table 1).

Table 1. Characterization of sand and silica.

\begin{tabular}{lllll} 
Origin & Type & $\begin{array}{l}\text { Density } \\
\left(\mathrm{g} / \mathrm{cm}^{3}\right)\end{array}$ & $\begin{array}{l}\text { BET } \\
\left(\mathrm{m}^{2} / \mathrm{g}\right)\end{array}$ & $\begin{array}{l}\text { Isotherm } \\
\text { Type }\end{array}$ \\
\hline Commercial & Silica gel & 1.87 & $353 \pm 2$ & IV \\
\hline USA & Silica extract & 2.18 & $272 \pm 5$ & II \\
\cline { 2 - 5 } & Sand & 2.76 & $<5$ & - \\
\cline { 2 - 5 } & $\begin{array}{l}\text { Silica extract - } \\
\text { R52-mCh- } \\
\text { mSOx-R5-6H }\end{array}$ & 2.18 & $119 \pm 5$ & II \\
\hline Ghana & Silica extract & 2.02 & $253 \pm 5$ & II \\
\cline { 2 - 5 } & Sand & 2.65 & $<5$ & - \\
\hline
\end{tabular}

Immobilization of the R5-proteins onto the silica (Fig. 1, steps 4 and 5) from crude protein extract results in 30-50\% uptake of total protein from the crude cell lysate (measured by the Bradford total protein assay), but this corresponds to $85-95 \%$ selective uptake of the R5-mCherry fusion proteins (Fig. 5b) measured via the inbuilt mCherry fluorescence. This is consistent with selective immobilization via the R5 tag. As the R5-mCherry protein becomes adsorbed, the silica turns pink and the supernatant becomes colorless (about 1hr; Fig. 1, step 5). SDS-PAGE gel following the process from crude lysate to R5-protein on silica (Fig. 4), shows that the $\mathrm{R} 5$ protein band ( $\mathrm{R} 52-\mathrm{mCh}-\mathrm{mSOx}-\mathrm{R} 5-6 \mathrm{H}$ at $73 \mathrm{kDa})$ almost completely disappears from the supernatant in contact with the silica, as the silica turns pink. The identity of the protein on the silica was confirmed by elution in non-physiological conditions from the silica [31,32] (under physiological conditions, the protein is not released). The R5 protein bands were confirmed in the eluent (Fig. 4).

General protein adsorption on silica is anticipated due to interaction with positively charged residues on the surface

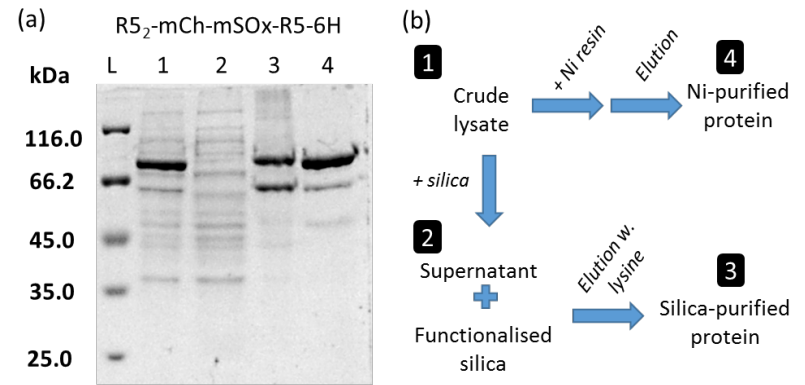

Fig. 4. Immobilization process from crude lysate as shown by (a) SDS page gel for R52-mCh-mSOx-R5-6H, showing in lane (1) crude lysate, (2) supernatant after immobilization of silica, (3) eluent off silica and (4) eluent from Ni. Purification pathway shown in (b). The band corresponding with the $\mathrm{R} 5{ }_{2}-\mathrm{mCh}-\mathrm{mSOx}-\mathrm{R} 5-6 \mathrm{H}$ is significantly diminished in the supernatant after immobilization on silica and reappears in the eluate from the silica, along with a small amount of other proteins. L indicates molecular weight 'Ladder'. The lower molecular weight band seen in the purified proteins indicates that the mCherry has undergone a partial hydrolysis of its chromophore acylimine bond during SDSPAGE analysis. 
of the protein. This has been shown for the reference material SOx-6H, without the R5, included in Fig. 5b. However, it can also be seen in this figure that the addition of the R5 peptide provides a tailored affinity site for silica, thereby incorporating a more selective immobilization capability for the protein without requiring additional chemical coupling reagents. R5 belongs to the proteins rich in arginine and lysine involved in silica precipitation (silaffins [30,33-35]). By adding the 19-amino acid R5 sequence (SSKKSGSYSGSKGSKRRIL) to mCherry the estimated pI for the protein shifts positive by $\sim 1$ unit for each R5 peptide unit added [36], due to the positively charged residues on the $\mathrm{R} 5$ polypeptide ( $\mathrm{K}$ and $\mathrm{R}$ ) [37]. These will interact with the negative charge of the silica surface [38]. The protein adsorption on the surface is expected to be entropically driven by the release of water molecules and sodium ions on the surface [39-42]. This should increase the affinity of the fusion protein for binding to silica.
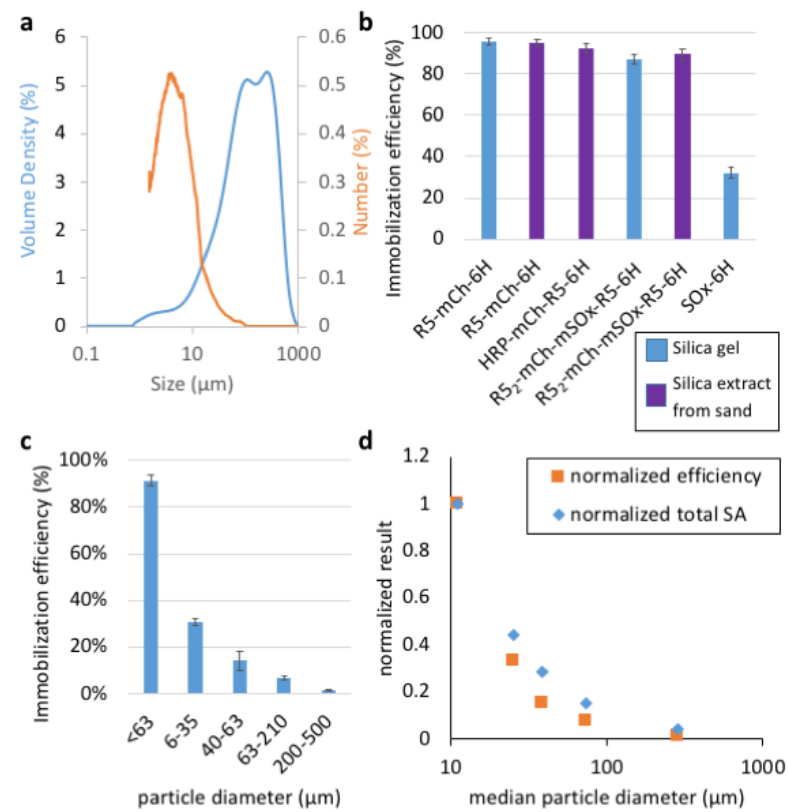

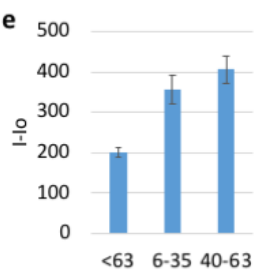

particle diameter $(\mu \mathrm{m})$

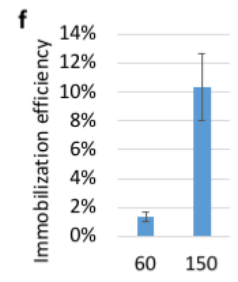

pore diameter $(\AA \AA)$

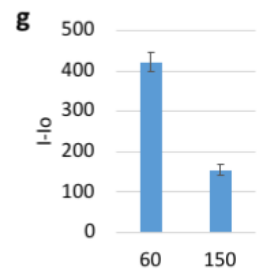

pore diameter $(\AA)$
Fig. 5. Immobilization efficiency and silica type. (a) Particle size (equivalent sphere diameter) distribution of the silica extract as measured by laser diffraction and the morphology microscope. (b) Immobilization of the R5$\mathrm{mCh}$-proteins on silica gel powder $(<63 \mu \mathrm{m}$, blue) and extracted silica (see (a) for size distribution, purple) $(5 \mathrm{mg})$, as measured by $\mathrm{mCh}$ fluorescence (except for SOx-6H - measured by Bradford assay). R52-mCh-mSOx-R5$6 \mathrm{H}$ was direct from lysate $(\sim 5 \mathrm{mg} / \mathrm{mL})$ while the others were Ni-purified protein (R5-mCh-6H $0.05 \mathrm{mg} / \mathrm{mL}, \mathrm{HRP}-\mathrm{mCh}-\mathrm{R} 5-6 \mathrm{H} 0.1 \mathrm{mg} / \mathrm{mL}$ ). (c) Immobilization efficiency across size fractions of various silica size classes. $75 \mu \mathrm{L}$ of crude lysate for $\mathrm{R} 52-\mathrm{mCh}-\mathrm{mSOx}-\mathrm{R} 5-6 \mathrm{H}$ (estimated $6.6 \mathrm{mg} / \mathrm{mL}$ ) added to $5 \mathrm{mg}$ of each silica type. (d) Total surface area (SA) and immobilization efficiency normalized to silica $<63 \mu \mathrm{m}$. (e) Activity of silica size classes for $10 \mu \mathrm{M}$ sarcosine. (f) Immobilization efficiency of silicas of 200$500 \mu \mathrm{m}$ particle diameter with different average pore diameter and $(\mathrm{g})$ corresponding activity in the presence of $10 \mu \mathrm{M}$ sarcosine.
These data raise the interesting question about the contribution of surface area and pore size in the protein immobilization and subsequent available activity of the protein. Figure 5b (using saturation concentrations of protein) does not suggest any difference in immobilization efficiency between the silica extracted from sand and the commercial silica gel. However, selecting discrete size classes shows the effect of size on immobilization efficiency (Fig. 5c). As particle size increases, immobilization efficiency decreases for the same concentration of $\mathrm{R} 52-\mathrm{mCh}-\mathrm{mSOx}-\mathrm{R} 5-6 \mathrm{H}$ in crude lysate $(45 \mu \mathrm{g}$ total protein/mg silica). This is expected since the surface area to volume ratio decreases with increase in particle diameter. Using a theoretical total surface area based on the median particle diameter and assuming spherical particles, the relative decrease in immobilization efficiency follows closely with the decrease in total surface area (Fig. 5d). This suggests that increasing the weight of larger silica for the same protein concentration, will increase immobilization efficiency (Fig. S2), indicating that protein concentration used in Fig. 5c is above saturation for available surface area of the larger sized particles of silica used.

It can also be seen that increasing the average pore size of commercial silica gel from $60 \AA$ to $150 \AA$ increases the immobilization efficiency for the same particle diameter (Fig. 5f). This is in line with the expected size of the proteins, as the unit cell of $\mathrm{mSOX}$ is reported as $71 \times 69.7 \times 72.9 \AA^{3}$ (PDB 3QSE for crystal structure for the complex of substrate-reduced $\mathrm{mSOx}$ with sarcosine); $\mathrm{mCh}$ is reported to have unit cell of $48.8 \times 42.9 \times 61 \AA^{3}$ (PDB 2H5Q for Crystal structure of $\mathrm{mCh}$ ) and the dimension of the native HRP (MW: $\sim 44 \mathrm{kDa}$ ) in a neutral buffer solution was predicted to be $62 \times 43 \times 12 \AA^{3}$ by a scanning tunneling microscopy study [43]. Hence, for commercial silica gels of $60 \AA$ and the extracted silicas showing non-porous behavior, immobilization is expected to be largely surface immobilization, whereas the $150 \AA$ pore silica accepts immobilization into the pore and can thus achieve a higher immobilization efficiency.

Nevertheless, correlation with protein activity also needs to be established. Klein et al [44] observed that green fluorescent protein (GFP) shows no significant adsorption to silica nanoparticles unless it is denatured, which they attribute to FPs being highly structured and not susceptible to loss of secondary structure. In contrast, red fluorescent proteins have been reported to be more susceptible to adsorption on silica but are denatured [45]. An initial examination of the resultant activity for the $\mathrm{R} 5$ immobilized proteins containing mCherry can be made from the mCherry fluorescence. Fluorescent lifetimes between 1.45-1.68ns were measured for all constructs with mCherry (Table S1). These are comparable with the reported lifetime for mCherry (1.46ns) [46] and therefore suggests that secondary structure (and the chromophore) is retained. Fig. S3 and Table S2 also shows that all the immobilized and solution R5-mCherry constructs exhibited nearly identical red fluorescence with excitation/emission peaks at 587/607 $\mathrm{nm}$. 


\subsection{Evaluation of the silica-R5-enzymes in bioassay}

Fig. 6c shows the calibration for sarcosine concentration using $\mathrm{R} 52-\mathrm{mCh}-\mathrm{mSOx}-\mathrm{R} 5-6 \mathrm{H}$ in solution with the coupled horseradish peroxidase (HRP) reaction (Fig. 6a). R52-mCh$\mathrm{mSOx}-\mathrm{R} 5-6 \mathrm{H}$, collected on silica from the crude protein lysate and washed (Fig. 1, step 6), can also be used directly for the diagnostic, without any further processing (Fig. 6b; Fig. S4). In this instance, as discussed above, the immobilization efficiency for $\mathrm{R}_{2}-\mathrm{mCh}-\mathrm{mSOx}-\mathrm{R} 5-6 \mathrm{H}$ on silica was $>90 \%$ and $>95 \%$ of the activity remained after 2 months of storage at room temperature (Fig. 6e), compared with $<20 \%$ for the protein in solution. The $\mathrm{K}_{\mathrm{m}}$ for the silica-R52-mCh-mSOxR5-6H (Fig. 1, step 7a; Fig. 6b; Fig. S4) was $16.5 \pm 0.9 \mathrm{mM}$ (compared with $16.5 \pm 0.4 \mathrm{mM}, 16.3 \pm 0.3 \mathrm{mM}$, and $16.1 \pm 0.4$ $\mathrm{mM}$ for $\mathrm{R}_{2}-\mathrm{mCh}-\mathrm{mSOx}-\mathrm{R} 5-6 \mathrm{H}, \mathrm{mSOx}-\mathrm{R} 5-6 \mathrm{H}$ and $\mathrm{mSOx}-$ $6 \mathrm{H}$ respectively in solution), which suggests that there has been no conformational impact on the sarcosine binding site due to the protein fusion or immobilization.

Although immobilization efficiency increased with an increase in pore diameter (Fig. 5f), the enzymatic activity on the $150 \AA$ pore silica is less than the $60 \AA$ pore silica for the same mSOx concentration (Fig. $5 \mathrm{~g}$ ). This suggests that despite the higher enzyme immobilization, the active site of the
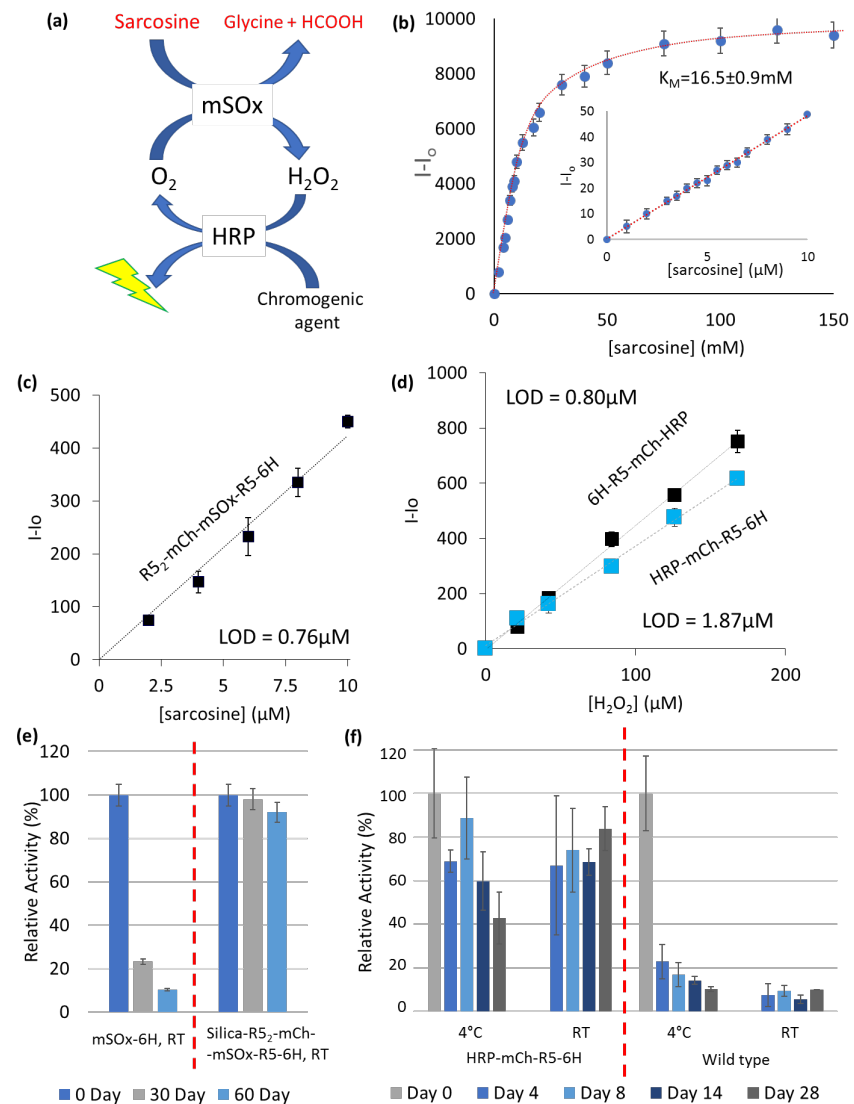

Fig. 6. Activity and stability of R5-mCh-Enz. (a) Scheme showing signal generation from 2-enzyme system combing $\mathrm{mSOx}$ and HRP. Calibration curve for (b) R5 $5_{2}-\mathrm{mCh}-\mathrm{mSOx}-\mathrm{R} 5-6 \mathrm{H}$ on silica and for free proteins in solution for (c) $\mathrm{R} 52-\mathrm{mCh}-\mathrm{mSOx}-\mathrm{R} 5-6 \mathrm{H}$ and (d) HRP constructs, $\lambda$ ex.530nm $/ \lambda$ em. $582 \mathrm{~nm}$ plotted against concentration. The isolated HRP showed a linear response to $\mathrm{H}_{2} \mathrm{O}_{2}$ in the range $0-200 \mu \mathrm{M}$, while $\mathrm{mSOx}$ is linear in the range of $0-10 \mu \mathrm{M}$. (e) Stability of immobilized $\mathrm{R} 5_{2}-\mathrm{mCh}$ $\mathrm{mSOx}-\mathrm{R} 5-6 \mathrm{H}$ as compared to $\mathrm{mSOx}-6 \mathrm{H}$, as measured by Trinder's colorimetric assay. (f) Stability of the wild type HRP and the HRP-mCh-R5-6H over 4 weeks at $4^{\circ} \mathrm{C}$ and ambient temperature, based on ABTS measurements of reaction rate. enzyme is not as accessible in the pore, or else additional interactions between the pore surface and the protein in the $3 \mathrm{D}$ pore space have caused denaturation of the active site. We can conclude that for the reaction with sarcosine, primarily surface immobilization is desirable and so no advantage is gained from pores having dimensions compatible with enzyme ingress.

HRP is widely used in bioassays, either as a label or to detect peroxide as co-product. However, recombinant HRP is a difficult protein to express, so that many commercially available peroxidases remain largely an isoenzyme mixture from plant extracts, requiring normal downstream processing purification and isolation steps. Recombinant HRP has a tendency to form inclusion bodies (IBs) with low yield [47] of active protein. However, both HRP-mCh-R5-6H and 6H-R5-mCh-HRP (type C HRP) have been transformed in E.coli NEB Turbo cells and expressed in E.coli Rosetta II and pLySs cells, respectively, without IB formation. This is possibly the result of the R5 sequence and the change in $\mathrm{pI}$ of the protein improving its solubility. The protein could therefore be isolated from the soluble cell fraction; $\mathrm{K}_{\mathrm{mS}}$ of $3.8 \mathrm{mM}$ and $1.6 \mathrm{mM}$ were measured for $6 \mathrm{H}-\mathrm{R} 5-\mathrm{mCh}-\mathrm{HRP}$ and HRP-mCh-R5-6H, respectively. This is consistent with the range of values reported in the literature for different HRP isoenzyme preparations [48], compared with a $\mathrm{K}_{\mathrm{m}}$ of $8 \mu \mathrm{M}$ for the commercially available mixture of acidic and basic isoenzymes (Fig. S8). The R5-enzyme retained 60$80 \%$ of its activity for more than 2 weeks, even at room temperature (the wild type enzyme lost $90 \%$ of its activity in 4 days, Fig. 6f). Fig. 6d shows that the response curve for both the $\mathrm{N}$ and $\mathrm{C}$ terminal recombinant proteins are similar and thus suggests that the fusion of $\mathrm{mCh}$ to $\mathrm{HRP}$ has not caused loss of enzyme activity.

Although this enzyme could be isolated directly from the cell lysate on silica, it needs folding with heme to activate the enzyme. No significant difference was observed in the specific activity of HRP-mCh-R5-6H if activation with heme occurred before or after the protein was immobilized on silica, however, a decrease was observed in the specific activity of 6H-R5-mCh-HRP if activation was done after immobilization (Table S3). In addition, the immobilization was less efficient when it occurred prior to reactivation, only $60 \%$ of total protein, as compared to $>75 \%$ total protein immobilized when it followed activation. With heme activation prior to immobilization, the heme-folded enzyme gave a specific protein immobilization efficiency on silica of $>90 \%$ (Fig. 5b) and was shown to work in tandem with the mSOxsilica in a sarcosine assay.

The optimal $\mathrm{pH}$ is 7.5 for WT SOx [49] but both the crude lysate and the immobilized $\mathrm{R} 52-\mathrm{mCh}-\mathrm{mSOx}-\mathrm{R} 5$ show greater retention of activity in the lower $\mathrm{pH}$ range than WT SOx (Fig. S5d). In contrast, the reported optimal $\mathrm{pH}$ is $6.0-$ 6.5 for HRP (by supplier). Experimentally, WT HRP showed similar activity across the range of 5.0-7.5 (Fig. $\mathrm{S} 5 \mathrm{~b}$ ). This broad range of activity is consistent with the mix of acidic and basic isozymes that make up the commercial enzyme. In comparison, the optimal $\mathrm{pH}$ of immobilized $6 \mathrm{H}-$ $\mathrm{R} 5-\mathrm{mCh}-\mathrm{HRP}$ (type C HRP) is expected to be at a higher $\mathrm{pH}$ range; 7.0-8.0 was found in this experiment, which matches better with the optimal $\mathrm{pH}$ of $\mathrm{R} 52-\mathrm{mCh}-\mathrm{mSOx}-\mathrm{R} 5-6 \mathrm{H}$.

The selectivity of recombinant $6 \mathrm{H}-\mathrm{R} 5-\mathrm{mCh}-\mathrm{HRP}$ and WT HRP was evaluated against dopamine, L-ascorbic acid, 
glucose and uric acid [50], with minimal cross reactivity observed (Fig S5a). The selectivity of recombinant and WT SOx was evaluated against glycine, L-proline, N-methyl-Lalanine, L-alanine, and creatinine [51-53] (Fig. S5c). Glycine, L-proline, L-alanine and creatinine show minimal cross reactivity with either recombinant or WT sarcosine oxidase at $10 \mu \mathrm{M}$. The concentration of alanine and creatinine in urine is approximately 1000 fold and 2000 fold higher than sarcosine, respectively [54-56], so corresponding final concentrations of both were also tested. Less than $5 \%$ cross reactivity was observed for $\mathrm{R} 52-\mathrm{mCh}-\mathrm{mSOx}-\mathrm{R} 5-6 \mathrm{H}$. In contrast, N-methyl-L-alanine results in $50-60 \%$ relative response for $\mathrm{R} 52-\mathrm{mCh}-\mathrm{mSOx}-\mathrm{R} 5-6 \mathrm{H}$ compared with $10 \%$ cross reactivity with the WT SOx. It is known that mSOx can oxidize other secondary amino acids like , N-methyl-Lalanine [52]. However, N-methyl-L-alanine is not reported as an interferent in urine samples so it is not expected to have an effect on sarcosine detection in urine.

\subsection{Designing an hourglass biosensor}

The previous section shows that the silica-enzyme can be directly used in bioassay with improved stability. Classical
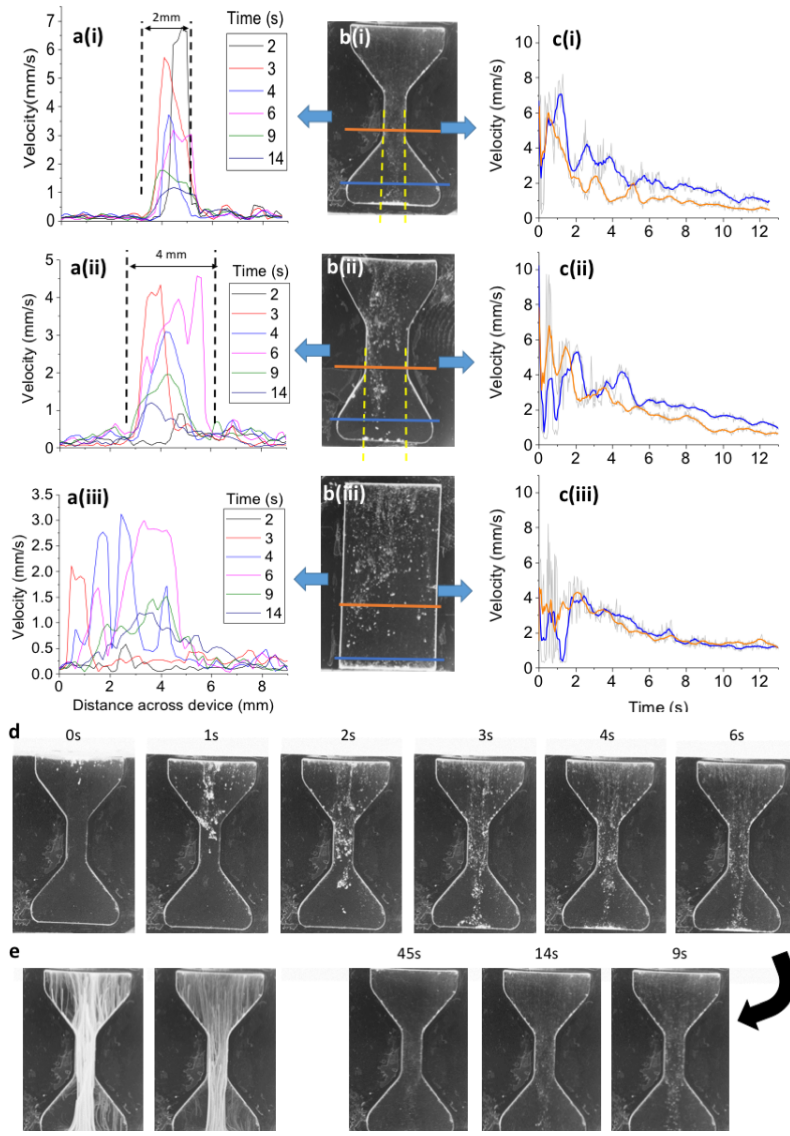

Fig. 7. Characterization of particle sedimentation for three basic hourglass designs (b(i)) narrow, (b(ii)) waisted and (b(iii)) parallel sided, showing sampling points in the middle (orange line) and towards the base (blue line). (a) Velocity profiles across the bottom line show particle sedimentation position and velocity with particle stream width less than the waist of the waisted designs, indicating the flow-focusing effect of eddies on either side of the falling particles. (c) Plot of the maximum velocity of the particles over time as they cross the indicated lines (middle, bottom). Bold lines show 10pts moving average for the middle (orange) and base (blue) data, grey shows raw data. (d) colour-inverted stills of particle sedimentation for selected time points after flipping. (e) Particle trajectories over time. diagnostic platforms have mostly used the immobilized protein as the stationary phase, where the sample diffuses transversally or laterally into the protein layer. For example, sample fill into a glucose test strip or lateral flow immunoassays. The latter have also employed packed beds of functionalized beads similar to the silica-enzymes produced here [57-60]. However, the silica particle format also allows other biosensor conformations to be explored. Taking inspiration from an hourglass (or sand glass), a design can be considered with the particles passing through the sample (Fig. 1, step 7b). Particle sedimentation is controlled by the internal shape and dimensions of the chamber (e.g. parallel, waisted, spiral etc.).

To explore the feasibility of this principle, with an inhomogeneous natural sample such as silica obtained from beach sand (see size distribution in Fig. 5a), we can compare the apparent activity of different sized particles in a dynamic mixing system: the relative enzymatic activity for the different sized silica particles (Fig. 5e) when suspended in solution and under rotation, showed the size fraction with the smallest particles $(<63 \mu \mathrm{m}$ silica gel 60$)$ had a lower response in the presence of $10 \mu \mathrm{M}$ sarcosine compared with the size classes containing only larger particles $(6-35 \mu \mathrm{m}$ and 40 $63 \mu \mathrm{m}$, Fig. 5e). Importantly, in this experiment, the larger particles cause more turbulent mixing of the solution whereas the smallest particles remain largely suspended in place, potentially resulting in the creation of local depletion zones. We propose therefore that in the hour glass model, the reaction will not be limited by the establishment of a depletion zone if the particles are sufficiently large to precipitate through the sample.

The influence of the funneling shape on the basic hourglass design was considered (Fig. S7) and it was found that the positioning of the particles following sedimentation depends on the "waist-dimensions" and axis of inversion of the device ("flip" or "tilt"). It is seen that by narrowing the waist of the hourglass, the R5-protein modified particles are guided to a resting position beneath the central channel, independent of inversion technique. This becomes clearer in Fig. 7a, where shadowgraphy and particle image velocimetry (PIV) map the particles falling in the first $14 \mathrm{~s}$ after inversion.

Table 2. Calculated and observed parameters for particles.

\begin{tabular}{|c|c|c|c|c|c|c|c|}
\hline & $\operatorname{radius}(\mu \mathrm{m})$ & 1 & 10 & 50 & 100 & 150 & 200 \\
\hline \multirow{5}{*}{ 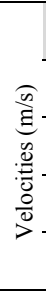 } & OBSERVED & -- & $\begin{array}{l}0.20 \\
\mathrm{x} 10^{-3}\end{array}$ & $\begin{array}{l}1.13 \\
\times 10^{-3}\end{array}$ & $\begin{array}{r}5.31 \\
\times 10^{-3} \\
\end{array}$ & $\begin{array}{r}7.02 \\
\times 10^{-3}\end{array}$ & $\begin{array}{l}10.2 \\
\mathrm{x} 10^{-3}\end{array}$ \\
\hline & $\begin{array}{l}\text { spherical parti- } \\
\text { cle }\end{array}$ & $\begin{array}{r}2.57 \\
\times 10^{-6}\end{array}$ & $\begin{array}{l}2.5 \\
\times 10^{4}\end{array}$ & $\begin{array}{r}5.79 \\
\times 10^{-3}\end{array}$ & $\begin{array}{r}1.96 \\
\times 10^{-2}\end{array}$ & $\begin{array}{r}3.69 \\
\times 10^{-2}\end{array}$ & $\begin{array}{r}5.49 \\
\times 10^{-6}\end{array}$ \\
\hline & $\begin{array}{l}\text { natural } \\
\text { sediment }\end{array}$ & $\begin{array}{r}1.91 \\
\times 10^{-6} \\
\end{array}$ & $\begin{array}{r}1.9 \\
\times 10^{4} \\
\end{array}$ & $\begin{array}{r}4.41 \\
\times 10^{-3} \\
\end{array}$ & $\begin{array}{r}1.49 \\
\times 10^{-2} \\
\end{array}$ & $\begin{array}{r}2.78 \\
\times 10^{-2} \\
\end{array}$ & $\begin{array}{r}4.06 \\
\times 10^{-2} \\
\end{array}$ \\
\hline & $\begin{array}{l}\text { particle } \\
\text { fraction } 0.2\end{array}$ & $\begin{array}{r}6.86 \\
\times 10^{-7} \\
\end{array}$ & $\begin{array}{r}6.82 \\
\times 10^{-5} \\
\end{array}$ & $\begin{array}{c}1.6 \\
\times 10^{-3} \\
\end{array}$ & $\begin{array}{c}6.2 \\
\times 10^{-3} \\
\end{array}$ & $\begin{array}{r}1.26 \\
\times 10^{-2} \\
\end{array}$ & $\begin{array}{c}1.9 \\
\times 10^{-2} \\
\end{array}$ \\
\hline & $\begin{array}{l}\text { particle } \\
\text { fraction } 0.3\end{array}$ & $\begin{array}{r}3.71 \\
\times 10^{-7} \\
\end{array}$ & $\begin{array}{r}3.69 \\
\times 10^{-5} \\
\end{array}$ & $\begin{array}{r}8.82 \\
\times 10^{4} \\
\end{array}$ & $\begin{array}{r}3.7 \\
\times 10^{-3} \\
\end{array}$ & $\begin{array}{r}7.81 \\
\times 10^{-3} \\
\end{array}$ & $\begin{array}{r}1.23 \\
\times 10^{-2} \\
\end{array}$ \\
\hline$\frac{\bar{v}}{c}$ & $\begin{array}{l}\text { Pe natural sedi- } \\
\text { ment }\end{array}$ & $\begin{array}{r}3.47 \\
\times 10^{-3} \\
\end{array}$ & 3.45 & $\begin{array}{r}4.01 \\
\times 10^{2} \\
\end{array}$ & $\begin{array}{r}2.71 \\
\times 10^{3} \\
\end{array}$ & $\begin{array}{r}7.58 \\
\times 10^{3} \\
\end{array}$ & $\begin{array}{r}1.48 \\
\times 10^{4} \\
\end{array}$ \\
\hline & $\begin{array}{l}\text { Pe particle frac- } \\
\text { tion } 0.2\end{array}$ & $\begin{array}{r}1.25 \\
\times 10^{-3}\end{array}$ & 1.24 & $\begin{array}{r}1.45 \\
\times 10^{2}\end{array}$ & $\begin{array}{r}1.13 \\
\times 10^{3}\end{array}$ & $\begin{array}{r}3.44 \\
\times 10^{3}\end{array}$ & $\begin{array}{r}6.91 \\
\times 10^{3}\end{array}$ \\
\hline
\end{tabular}

\# Matches between calculated and observed are indicated by shaded cells. No observed velocities are reported for particles $r<10 \mu \mathrm{m}$ due to limitations of camera resolution. 
Immediately following inversion, plumes of large particles or agglomerates entraining smaller particles, with effective radii in the range of $100-200 \mu \mathrm{m}$ fall with a maximum terminal velocity estimated from the PIV data of $1.3-11.3 \mathrm{x}$ $10^{-3} \mathrm{~m} / \mathrm{s}$. The driving buoyancy force behind the plumes is the gravity acting on the higher density of the particles temporarily suspended within a fluid, and the sedimentation patterns can be seen visually in Fig. 7d. At these velocities and particle size, the Reynolds number $(\mathrm{Re})$ is in the region $0.2-$ 7.6, outside the region in which Stokes Law applies (Re $<0.1)$. For all the designs, the experimental velocity data, recorded near the base of the device (blue line, Fig. 7b) are lower than expected for a smooth, spherical particle of the same diameter, calculated according to the numerical equation developed by Guo [61], disregarding interactions with other particles or the fluid (Table 2). This is anticipated from consideration of the irregular shape of natural silica extracted from sand (Fig. S1) and resulting frictional forces. Zhiyao et al [62] proposed a formula that adjusts for the effect of particle shape, however, this does not fully account for the observed decrease in terminal velocity (Table 2). To account for this discrepancy, the action of the fluid displacement is considered during sedimentation. Despite an overall volume fraction of particles in the device $<0.003$, the local
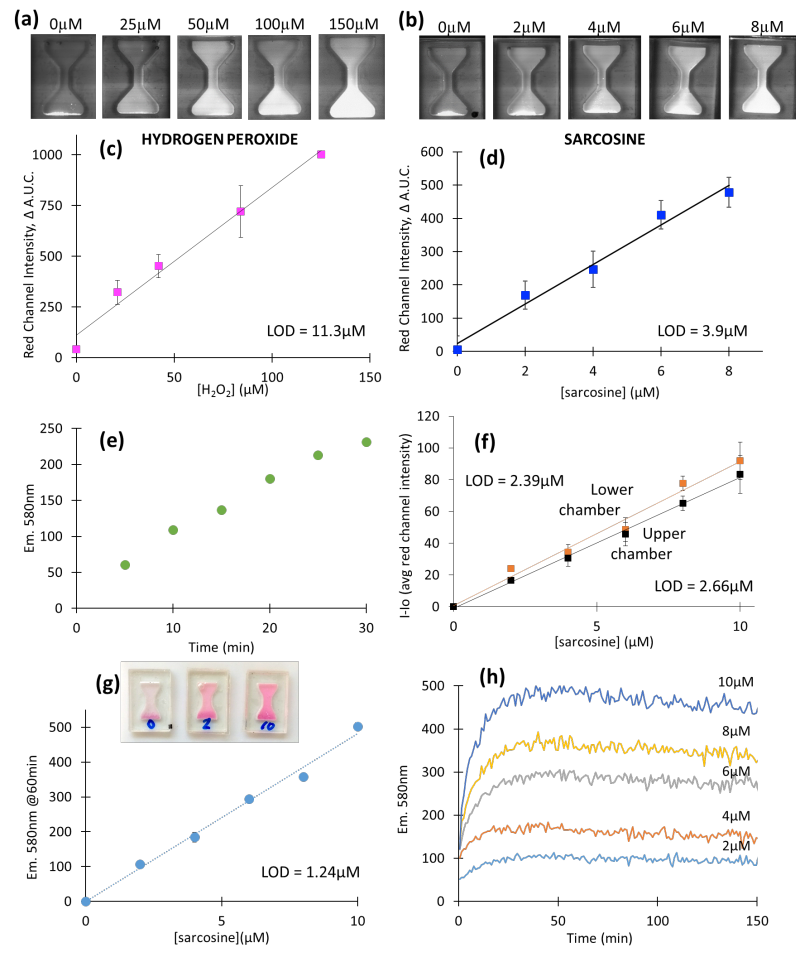

Fig. 8. Immobilized protein on silica extracted from sand used directly in the hourglass for (a) $\mathrm{H}_{2} \mathrm{O}_{2}$ (with HRP-mCh-R5-(6H) silica) and (b) sarcosine (with silica-R5 $5_{2}-\mathrm{mCh}-\mathrm{mSOx}-\mathrm{R} 5-6 \mathrm{H}$ ). Images taken $7 \mathrm{~min}$ after sample addition. The change in fluorescence, integrating the red channel intensity at right angles from the base along the middle line of the hourglass over 5 min plotted against (c) $\mathrm{H}_{2} \mathrm{O}_{2}$ and (d) sarcosine concentration, following two inversions of $60 \mathrm{~s}$. The different concentration ranges measured for these two "silica-enzymes" reflect their different $\mathrm{K}_{\mathrm{m}}$. (e) Fluorescence increase with device inversions/time $6 \mu \mathrm{M}$ sarcosine (f) Average red channel intensity of the upper and lower chamber of the device after 6 inversions. (g) Endpoint assay for 50uL sample at $60 \mathrm{~min}$ showing a linear relationship of intensity with [sarcosine] with insert showing visual detection of fluorescence in $50 \mu \mathrm{L}$ mini-hourglass at $60 \mathrm{~min}$. (h) Consumption of sarcosine with time, showing completion by $\sim 40 \mathrm{~min}$. volume fraction of particles in the plumes is much higher. Immediately after inversion, hindered settling, from the upward motion of the displaced fluid interacting with the particle(s) [63], can thus result in lower velocities. As can be seen from Table 2, the experimental data in the initial plumes are comparable with an apparent particle fraction of $0.2-0.4$ for the particles falling initially of $r>50 \mu \mathrm{m}$. Smaller less clustered particles falling after the initial plumes, on the other hand, show less hindered settling and behave more like smaller volume fraction natural sediment.

The influence of the waist constriction is highlighted in Fig. 7c(i-iii), where maximum particle velocity is compared in the middle of the device (orange line) and near the base (blue line). Although the maximum velocity (but not particle position) near the base of the device is nearly independent of the design, there is a clear retardation of sedimentation within the narrow channel compared with the other designs. The straight-sided and wide-waisted hourglasses achieve little focusing of the particle sedimentation (Fig. 7a(ii-iii)), whereas the narrow hourglass shape (Fig. 7a(i)) leads to the central focusing of the particle sedimentation. This defines the final position of the particles in an area beneath the central tube (irrespective of inversion axis) and creates a reproducible inversion pattern with the particles always starting from the same location for each inversion. This is not seen in the other designs (Fig. 7b/c(ii-iii)). Since the enzyme linked assay is a dynamic reaction process, this reproducible sedimentation ensures that a reproducible process occurs and thus lends itself to a biosensor platform.

\subsection{Hourglass biosensor demonstration}

Despite the high volume density of small particles in the silica extracted from sand, entrainment in the initial plumes with larger particles provides an efficient precipitation of the heterogeneous silica. Sampling from the overall trajectory of particle settling, as shown in Fig. 7e, predicts that $80-90 \%$ of the cell volume is 'sampled' on each inversion by particles passing through the cell between 2 - 14s after each inversion. This provides an indicative efficiency for the design. Based on their estimated velocities and particle size, the Péclet number (Table 2) suggests that particles with radii $<10 \mu \mathrm{m}$ would be in a diffusion controlled regime. The smallest particles which didn't become entrained in the plumes with $\operatorname{Re}<0.1$, continue to fall for circa 60 s after inversion in a laminar fashion.

Fig. 8 demonstrates the hourglass format containing HRP-mCh-R5-(6H)-silica or silica-R52-mCh-mSOx-R5-6H for peroxide and sarcosine measurement respectively. Fig. $8 \mathrm{a}$ and $\mathrm{b}$ show visually that the fluorescence increases in the hourglass with concentration of enzyme substrate. To obtain a fully quantitative output, the fluorescence intensity was measured and the intensity plotted on a trajectory perpendicular to the hourglass base through the central line of the cell. The area under this curve (AUC) shows a linear relationship with concentration for both hydrogen peroxide and sarcosine (Fig. 8c and 8d following 2 inversions).

However, this is a dynamic process and Fig. 8e follows the increase in fluorescence after further inversions revealing a linear relationship with time, even for 30 inversions (=30 min). This leads to a robust time insensitive quantitative measurement protocol: for example, taking the change 
in fluorescence for the same $\Delta \mathrm{t}$ at any point along that time curve in Fig. 8e would produce the same result. Fig. 8f compares the result at $7 \mathrm{~min}$ ( 6 inversions), for the top and bottom compartments, showing good linearity and reproducibility. The detection range $(2.5$ to $10 \mu \mathrm{M})$ for this simple assay format corresponds to the range required to detect elevated sarcosine levels in the urine of prostate cancer patients $(>5 \mu \mathrm{M}$ $[25,26])$. A trial with prostate cancer patients using this assay will be reported elsewhere [64].

By contrast, an end-point assay can also be designed that uses a smaller sample. For example, with $50 \mu \mathrm{L}$ total sample, consumption is achieved within circa 40 mins (Fig. 8h) producing a linear relationship with sarcosine concentration (Fig. 8g). This assay can be extremely sensitive and valuable where only very small samples are available. For example, Fig. $8 \mathrm{~g}$ insert shows a $50 \mu \mathrm{L}$ hour glass imaged at $60 \mathrm{~min}$ with clear visual distinction between 0,2 and $10 \mu \mathrm{M}$ sarcosine.

\section{Conclusions}

In its study on increasing access to diagnostics in LMICs, WHO reports that diagnostic tests are not affordable in these vulnerable countries, where the burden of disease is highest [65]. The absence of affordable medical diagnostics undermines the cornerstones of effective clinical decision-making [66]. Clinicians often don't have enough information, so syndromic or presumptive treatment is particularly common. Lack of diagnostics leading to unnecessary or inappropriate use of antibiotics is one of the outcomes and has been cited as the "Achilles Heel" in combating antimicrobial resistance $[67,68]$.

Makerere has suggested that there is a need to empower local people with improved healthcare knowledge and services $[69,70]$ and a workshop held during the Geneva Health Forum 2016 considered how to increase access to quality diagnostics in LMICs using social innovation [71], centering production around local communities, with a target of minimal cost per patient, to improve patient outcome [72]. However, even basic raw materials to achieve this vision have to be imported at too high a cost due to a complex manufacturing and distribution chain [73] without global Purchasing Power Parity (PPP). This prohibits uptake in low income countries [74], so the development of local enterprises and infrastructure is not competitive. Often the local product, even when marketed at an unsustainable small margin, would still be more expensive than the imported finished (unaffordable) product [75].

In this viscous circle, in vitro diagnostics that are available in low income countries are often the result of international donors supporting disease-specific initiatives. The enormous value of these initiatives is seen for example, in HIV and malaria testing [6], but tests need to become selfsustaining [68], without charitable donor commitment. Furthermore, even in relatively well supported urban laboratories that have been equipped by donor and NGO investment, instrumentation sits idle since reagent and kit costs have rendered it beyond budget [76].

The research reported herein has taken the first step to integrate the protein design for a diagnostic and reduce downstream processing and the use of chemical coupling reagents. It has demonstrated a protein design that employs an affinity binding sequence for silica in fusion with the central assay reagent protein ( $\mathrm{SOx}, \mathrm{HRP}$ ) targeting the analyte. It was shown that the production could be followed easily without major infrastructure resources, by incorporation of a colored protein in the fusion construct design. This could be used for production control and monitoring of subsequent activity of protein in storage.

Using silica/sand as a protein carrier also provides a means of easy protein collection by adsorption and silicaprecipitation (cf magnetic particles $[19,77,78]$ ), and presentation of a versatile protein-silica preparation for many classical bioassay formats and microfluidics, as well as more innovative designs (Fig. 1, step 7b). Depending on the choice of functional enzyme, the silica-R5-protein constructs can be used for either small molecule detection, immunoassay or nucleic acid amplification, e.g. polymerases like Taq and Bst. The wide availability of sand worldwide, provides a low-cost substrate acting both as carrier and stabilizer for the protein (in comparison to the soluble protein, the 'sand-enzymes' were seen to be stable for weeks at room temperature $\left.\left(22^{\circ} \mathrm{C}\right)\right)$, as well as reducing the complexity of the isolation and purification process. We have demonstrated a preliminary example of the "gene to diagnostic" pathway, highlighting the use of silica as a protein carrier for SOx. A novel biosensor platform was conceived inspired by an hourglass. Using PIV, the sedimentation pattern was studied and an hourglass with narrow waist shown to give the best control of particle trajectory. This was demonstrated for sarcosine measurement and sarcosine determination shown in the clinically useful range in urine for prostate cancer $[25,26]$. Results from the study of the device used with urine samples from patients with prostate cancer will be reported shortly [64].

Since affinity peptides have been identified for an increasing range of substrates [79] including materials like cellulose and lignin, this approach has broad applicability to abundant naturally occurring materials. Such molecular and synthetic biology tools $[80,81]$ may help reduce hurdles to local production in LMICs. Furthermore, decentralized production with a low carbon footprint is increasingly important globally and taking a holistic approach to an integrated diagnostic design may be more flexible for different needs worldwide.

\section{Supporting Information}

Additional experimental details and characterization are given in supplementary information.

The raw data required to reproduce these findings are available to download from Cambridge University Data Repository (url to be added at proof). The processed data required to reproduce these findings are available to download from Cambridge University Data Repository (url to be added at proof).

Corresponding Author
* lisa.hall@biotech.cam.ac.uk 


\section{Acknowledgement}

Funding from Royal Society IC160089 is acknowledged in designing the protein integration. The Gates Cambridge Trust is acknowledged for scholarship to CJH. The Cambridge Trust is acknowledged for a Commonwealth Scholarship to DS. Members of Cambridge Analytical Biotechnology including David Bailey and Ziyan Zhao are acknowledged for their work on protein constructs that provided a starting library for this work.

\section{References}

[1] C.H.D. Jones, J. Howick, N.W. Roberts, C.P. Price, C. Heneghan, A. Plüddemann, et al., Primary care clinicians' attitudes towards point-of-care blood testing: A systematic review of qualitative studies, BMC Fam. Pract. 14 (2013) 1-9. doi:10.1186/14712296-14-117.

[2] A. St John, C.P. Price, Existing and Emerging Technologies for Point-of-Care Testing., Clin. Biochem. Rev. 35 (2014) 155-67. http://www.pubmedcentral.nih.gov/articlerender.fcgi?artid=420 $4237 \&$ tool $=$ pmcentrez\&rendertype $=$ abstract .

[3] K. Taylor, M. Chisambi, Working differently to provide early diagnosis: Improving access to diagnostics, 2013

[4] K. Haney, P. Tandon, R. Divi, M.R. Ossandon, H. Baker, P.C. Pearlman, The Role of Affordable, Point-of-Care Technologies for Cancer Care in Low- and Middle-Income Countries: A Review and Commentary, IEEE J. Transl. Eng. Heal. Med. 5 (2017) 1-14. doi:10.1109/JTEHM.2017.2761764.

[5] M. Plummer, C. de Martel, J. Vignat, J. Ferlay, F. Bray, S. Franceschi, Global burden of cancers attributable to infections in 2012: a synthetic analysis, Lancet Glob. Heal. 4 (2016) e609e616. doi:10.1016/S2214-109X(16)30143-7.

[6] N. Singh, D. Abrol, Challenge of In-vitro Diagnostics for Resource Poor Settings: An Assessment, New Delhi, 2014.

[7] D. Beran, J.S. Yudkin, M. De Courten, Access to care for patients with insulin-requiring diabetes in developing countries: Case studies of Mozambique and Zambia, Diabetes Care. 28 (2005) 2136-2140. doi:10.2337/diacare.28.9.2136.

[8] G.R. Dagenais, H.C. Gerstein, X. Zhang, M. McQueen, S. Lear, P. Lopez-Jaramillo, et al., Variations in diabetes prevalence in low-, middle-, and high-income countries: results from the prospective urban and rural epidemiological study, Diabetes Care. 39 (2016) 780-787. doi:10.2337/dc15-2338.

[9] F.B. Hu, Globalization of diabetes: The role of diet, lifestyle, and genes, Diabetes Care. 34 (2011) 1249-1257. doi:10.2337/dc110442 .

[10] G. Mulgan, S. Tucker, R. Ali, B. Sanders, Social Innovation: what it is, why it matters, how it can be accelerated, The Young Foundation,

https://youngfoundation.org/publications/social-innovationwhat-it-is-why-it-matters-how-it-can-be-accelerated/.

[11] K.S. Boles, K. Kannan, J. Gill, M. Felderman, H. Gouvis, B. Hubby, et al., Digital-to-biological converter for on-demand production of biologics, Nat. Biotechnol. 35 (2017) 672-675. doi:10.1038/nbt.3859.

[12] K. Pardee, S. Slomovic, P.Q. Nguyen, J.W. Lee, N. Donghia, D. Burrill, et al., Portable, On-Demand Biomolecular Manufacturing, Cell. $167 \quad$ (2016) 248-259.e12. doi:10.1016/j.cell.2016.09.013.

[13] R. McNerney, Diagnostics for Developing Countries, Diagnostics. $\quad 5 \quad$ (2015) 200-209. doi:10.3390/diagnostics5020200.

[14] M.M. Gong, D. Sinton, Turning the Page: Advancing PaperBased Microfluidics for Broad Diagnostic Application, Chem. Rev. 117 (2017) 8447-8480. doi:10.1021/acs.chemrev.7b00024.

[15] K. Yamada, H. Shibata, K. Suzuki, D. Citterio, Toward practical application of paper-based microfluidics for medical diagnostics: state-of-the-art and challenges, Lab Chip. 17 (2017) 1206-1249. doi:10.1039/c6lc01577h.

[16] C.M. Pandey, S. Augustine, S. Kumar, S. Kumar, S. Nara, S. Srivastava, et al., Microfluidics Based Point-of-Care Diagnostics, Biotechnol. J. 13 (2018) 1-11. doi:10.1002/biot.201700047.

[17] N. Jornet-Martínez, P. Campíns-Falcó, E.A.H. Hall, Zein as biodegradable material for effective delivery of alkaline
[27] J. Peccoud, Synthetic Biology:fostering the cyber-biological $\begin{array}{lllll}\text { revolution, Synth. } & \text { Biol. } & 1 & \text { (2016) } & 1-7 .\end{array}$ doi:10.1093/synbio/ysw001.

[28] V. Vaibhav, U. Vijayalakshmi, S.M. Roopan, Agricultural waste as a source for the production of silica nanoparticles, Spectrochim. Acta - Part A Mol. Biomol. Spectrosc. 139 (2015) 515-520. doi:10.1016/j.saa.2014.12.083.

[29] Z. Munasir, T. Triwikantoro, M. Zainuri, D. Darminto, Synthesis of $\mathrm{SiO} 2$ nanopowders containing quartz and cristobalite phases from silica sands, Mater. Sci. Pol. 33 (2015) 47-55. doi:10.1515/msp-2015-0008.

[30] N. Kröger, R. Deutzmann, M. Sumper, Polycationic peptides from diatom biosilica that direct silica nanosphere formation, Science (80-. $) .286 \quad$ (1999) 1129-1132. doi:10.1126/science.286.5442.1129.

[31] S. Ghose, T.M. McNerney, B. Hubbard, Preparative protein purification on underivatized silica, Biotechnol. Bioeng. 87 (2004) 413-423. doi:10.1002/bit.20125.

[32] J. Soto-Rodríguez, B.L. Coyle, A. Samuelson, K. Aravagiri, F. Baneyx, Affinity purification of Car9-tagged proteins on silica matrices: Optimization of a rapid and inexpensive protein purification technology, Protein Expr. Purif. 135 (2017) 70-77. doi:10.1016/j.pep.2017.05.003.

[33] I.E. Pamirsky, K.S. Golokhvast, Silaffins of diatoms: From applied biotechnology to biomedicine, Mar. Drugs. 11 (2013) 3155-3167. doi:10.3390/md11093155.

[34] M. Sumper, N. Kröger, Silica formation in diatoms: the function of long-chain polyamines and silaffins, J. Mater. Chem. 14 (2004) 2059-2065. doi:10.1039/B401028K.

[35] L. Senior, M.P. Crump, C. Williams, P.J. Booth, S. Mann, A.W. Perriman, et al., Structure and function of the silicifying peptide R5, J. Mater. Chem. B. 3 (2015) 2607-2614. doi:10.1039/C4TB01679C.

[36] E. Gasteiger, C. Hoogland, A. Gattiker, S. Duvaud, M.R. Wilkins, R.D. Appel, et al., Protein Identification and Analysis Tools on the ExPASy Server, in: J.M. Walker (Ed.), Proteomics Protoc. Handb., 2005: pp. 571-607. https://web.expasy.org/protparam/.

[37] S. V. Patwardhan, F.S. Emami, R.J. Berry, S.E. Jones, R.R. Naik, 
O. Deschaume, et al., Chemistry of aqueous silica nanoparticle surfaces and the mechanism of selective peptide adsorption, J. Am. Chem. Soc. 134 (2012) 6244-6256. doi:10.1021/ja211307u.

[38] C.C. Lechner, C.F.W. Becker, Silaffins in silica biomineralization and biomimetic silica precipitation, Mar. Drugs. 13 (2015) 5297-5333. doi:10.3390/md13085297.

[39] V. Puddu, C.C. Perry, Peptide adsorption on silica nanoparticles: Evidence of hydrophobic interactions, ACS Nano. 6 (2012) 6356-6363. doi:10.1021/nn301866q.

[40] S.K. Parida, S. Dash, S. Patel, B.K. Mishra, Adsorption of organic molecules on silica surface, Adv. Colloid Interface Sci. 121 (2006) 77-110. doi:10.1016/j.cis.2006.05.028.

[41] E. Eteshola, L.J. Brillson, S.C. Lee, Selection and characteristics of peptides that bind thermally grown silicon dioxide films, Biomol. $\quad$ Eng. 22 (2005) 201-204. doi:10.1016/j.bioeng.2005.09.004.

[42] A.A. Vertegel, R.W. Siegel, J.S. Dordick, Silica nanoparticle size influences the structure and enzymatic activity of adsorbed lysozyme, Langmuir. $20 \quad$ (2004) 6800-6807. doi:10.1021/la0497200.

[43] J. Zhang, Q. Chi, S. Dong, E. Wang, In situ electrochemical scanning tunnelling microscopy investigation of structure for horseradish peroxidase and its electricatalytic property, Bioelectrochemistry Bioenerg. $39 \quad$ (1996) 267-274. doi:http://dx.doi.org/10.1016/0302-4598(95)01893-X.

[44] G. Klein, S. Devineau, J.C. Aude, Y. Boulard, H. Pasquier, J. Labarre, et al., Interferences of silica nanoparticles in green fluorescent protein folding processes, Langmuir. 32 (2016) 195202. doi:10.1021/acs.langmuir.5b03890.

[45] M. Soumbo, A. Pugliara, M.-C. Monje, C. Roques, B. Despax, C. Bonafos, et al., Physico-Chemical Characterization of the Interaction of Red Fluorescent Protein-DsRed With Thin Silica Layers, IEEE Trans. Nanobioscience. 15 (2016) 412-417. doi:10.1109/TNB.2016.2547895.

[46] B. Seefeldt, R. Kasper, T. Seidel, P. Tinnefeld, K.J. Dietz, M. Heilemann, et al., Fluorescent proteins for single-molecule fluorescence applications, J. Biophotonics. 1 (2008) 74-82. doi:10.1002/jbio.200710024.

[47] T. Gundinger, O. Spadiut, A comparative approach to recombinantly produce the plant enzyme horseradish peroxidase in Escherichia coli, J. Biotechnol. 248 (2017) 15-24. doi:10.1016/j.jbiotec.2017.03.003.

[48] F.W. Krainer, R. Pletzenauer, L. Rossetti, C. Herwig, A. Glieder, O. Spadiut, Purification and basic biochemical characterization of 19 recombinant plant peroxidase isoenzymes produced in Pichia pastoris, Protein Expr. Purif. 95 (2014) 104-112. doi:10.1016/j.pep.2013.12.003.

[49] Y. Nishiya, T. Imanaka, Alteration of substrate specificity and optimum $\mathrm{pH}$ of sarcosine oxidase by random and site-directed mutagenesis, Appl. Environ. Microbiol. 60 (1994) 4213-4215.

[50] S. Chairam, P. Buddhalee, M. Amatatongchai, A Novel Hydrogen Peroxide Biosensor Based on Horseradish Peroxidase Immobilized on Poly ( aniline- co - o -aminobenzoic acid ) Modified Glassy Carbon Electrode Coated with Chitosan Film, Int. J. Electrochem. Sci.,. 8 (2013) 10250-10264.

[51] Y. Nishiya, S. Nakano, K. Kawamura, Y. Abe, Monomeric sarcosine oxidase acts on both L- and D-substrates, J. Anal. BioScience. 35 (2012) 426-430.

[52] M.A. Wagner, M.S. Jorns, Monomeric sarcosine oxidase: 2. Kinetic studies with sarcosine, alternate substrates, and a substrate analogue, Biochemistry. 39 (2000) 8825-8829. doi:10.1021/bi000350y.

[53] P. Kumar, R. Jaiwal, C.S. Pundir, An improved amperometric creatinine biosensor based on nanoparticles of creatininase, creatinase and sarcosine oxidase, Anal. Biochem. 537 (2017) 4149. doi:10.1016/j.ab.2017.08.022.

[54] F. Jentzmik, C. Stephan, K. Miller, M. Schrader, A. Erbersdobler, G. Kristiansen, et al., Sarcosine in Urine after Digital Rectal Examination Fails as a Marker in Prostate Cancer Detection and Identification of Aggressive Tumours, Eur. Urol. 58 (2010) 1218. doi:10.1016/j.eururo.2010.01.035.

[55] A. Hewavitharana, Re: Florian Jentzmik, Carsten Stephan, Kurt Miller, et al. Sarcosine in Urine after Digital Rectal Examination Fails as a Marker in Prostate Cancer Detection and Identification of Aggressive Tumours. Eur Urol. In press. doi:10.1016/j.eururo.2010.01.035, Eur Urol. 58 (2010) e39-e40. doi:S0302-2838(10)00430-6 [pii] \r10.1016/j.eururo.2010.05.003.
D.B. Barr, L.C. Wilder, S.P. Caudill, A.J. Gonzalez, L.L. Needham, J.L. Pirkle, Urinary creatinine concentrations in the U.S. population: Implications for urinary biologic monitoring measurements, Environ. Health Perspect. 113 (2005) 192-200. doi:10.1289/ehp.7337.

[57] E. Verpoorte, Beads and chips: new recipes for analysis, Lab a Chip Focus. 3 (2003) 60N-68N. doi:10.1039/b313217j.

[58] T. Buranda, J. Huang, V.H. Perez-Luna, B. Schreyer, L.A. Sklar, G.P. Lopez, Biomolecular recognition on well-characterized beads packed in microfluidic channels, Anal. Chem. 74 (2002) 1149-1156. doi:10.1021/ac0109624.

[59] S. Senapati, A.R. Mahon, J. Gordon, C. Nowak, S. Sengupta, T.H.Q. Powell, et al., Rapid on-chip genetic detection microfluidic platform for real world applications, Biomicrofluidics. 3 (2009) e1-e7. doi:10.1063/1.3127142.

[60] J. Křenková, F. Foret, Immobilized microfluidic enzymatic reactors, Electrophoresis. 25 (2004) 3550-3563. doi:10.1002/elps.200406096.

[61] J. Guo, Logarithmic matching and its applications in computational hydraulics and sediment transport, J. Hydraul. Res. 40 (2002) 555-565. doi:10.1080/00221680209499900.

[62] S. Zhiyao, W. Tingting, X. Fumin, L. Ruijie, A simple formula for predicting settling velocity of sediment particles, Water Sci. Eng. 1 (2008) 37-43. doi:10.1016/S1674-2370(15)30017-X.

[63] J.F. Richardson, W.N. Zaki, The sedimentation of a suspension of uniform spheres under conditions of viscous flow, Chem. Eng. Sci. 3 (1954) 65-73. doi:10.1016/0009-2509(54)85015-9.

[64] N. Jornet-Martínez, C.J. Henderson, P. Campins-Falco, R. Daly, E.A.H. Hall, A Silica-Affinity Sarcosine Oxidase in a Biosensor Model for Sarcosine Determination in Prostatic Carcinoma, (Submitted). (2018).

[65] WHO, Increasing Access to Diagnostics Through Technology Transfer and Local Production, Geneva, 2011. http://www.who.int/phi/en/.

[66] L.M. Bebell, A.N. Muiru, Antibiotic use and emerging resistance: How can resource-limited countries turn the tide?, Glob. Heart. 9 (2014) 347-358. doi:10.1016/j.gheart.2014.08.009.

[67] M.S. Dryden, J. Cooke, P. Davey, Antibiotic stewardship-more education and regulation not more availability?, J. Antimicrob. Chemother. 64 (2009) 885-888. doi:10.1093/jac/dkp481.

[68] I.N. Okeke, R.W. Peeling, H. Goossens, R. Auckenthaler, S.S. Olmsted, J.F. De Lavison, et al., Diagnostics as essential tools for containing antibacterial resistance, Drug Resist. Updat. 14 (2011) 95-106. doi:10.1016/j.drup.2011.02.002.

[69] C.G. Orach, Health equity: challenges in low income countries. Afr. Health Sci. 9 (2009) S49-51. http://www.pubmedcentral.nih.gov/articlerender.fcgi?artid=287 $7288 \&$ tool $=$ pmcentrez\&rendertype $=$ abstract.

[70] M. Moran, The grand convergence: Closing the divide between public health funding and global health needs, PLoS Biol. 14 (2016) 1-10. doi:10.1371/journal.pbio.1002363.

[71] K.D. Koirala, L. van Niekerk, P.J. Garcia, R. Peeling, N. Kumar, A. Vyas, et al., Improving Access to Quality Diagnostic Tools in Low and Middle Income Countries ( LMICs ) Through Social Innovation-Lessons Learnt, Int. J. Public Heal. Saf. 2 (2017) 12.

[72] S. Horton, R. Sullivan, J. Flanigan, K.A. Fleming, M.A. Kuti, L.M. Looi, et al., Delivering modern, high-quality, affordable pathology and laboratory medicine to low-income and middleincome countries: a call to action, Lancet. 6736 (2018) 1-12. doi:10.1016/S0140-6736(18)30460-4.

[73] P. Yadav, Health Product Supply Chains in Developing Countries: Diagnosis of the Root Causes of Underperformance and an Agenda for Reform, Heal. Syst. Reform. 1 (2015) 142154. doi:10.4161/23288604.2014.968005.

[74] J.-P. Allain, O. Opare-Sem, Screening and diagnosis of HBV in low-income and middle-income countries, Nat. Rev. Gastroenterol. Hepatol. 13 (2016) 643-653. doi:10.1038/nrgastro.2016.138.

[75] N. Singh, D. Abrol, In-vitro diagnostics (IVDs) innovations for resource-poor settings: The Indian experience, African J. Sci. Technol. Innov. Dev. 9 (2017) 617-636. doi:10.1080/20421338.2017.1359465.

[76] M.S. Cordray, R.R. Richards-Kortum, Review: Emerging nucleic acid-based tests for point-of-care detection of malaria, Am. J. Trop. Med. Hyg. 87 (2012) 223-230. doi:10.4269/ajtmh.2012.11-0685.

[77] C. Xu, K. Xu, H. Gu, X. Zhong, Z. Guo, R. Zheng, et al., 
Nitrilotriacetic acid-modified magnetic nanoparticles as a general agent to bind histidine-tagged proteins, J. Am. Chem. Soc. 126 (2004) 3392-3393. doi:10.1021/ja031776d.

[78] H. Gu, P.L. Ho, K.W.T. Tsang, L. Wang, B. Xu, Using biofunctional magnetic nanoparticles to capture vancomycinresistant enterococci and other gram-positive bacteria at ultralow concentration, J. Am. Chem. Soc. 125 (2003) 15702-15703. doi:10.1021/ja0359310.

[79] E.A.H. Hall, S. Chen, J. Chun, Y. Du, Z. Zhao, A molecular biology approach to protein coupling at a biosensor interface, Trends Anal. Chem. 79 (2016) 247-256. doi:10.1016/j.trac.2016.01.024.

[80] R.A. Sheldon, S. van Pelt, Enzyme immobilisation in biocatalysis: why, what and how, Chem. Soc. Rev. 42 (2013) 6223-6235. doi:10.1039/C3CS60075K.

[81] N.R. Mohamad, N.H.C. Marzuki, N.A. Buang, F. Huyop, R.A Wahab, An overview of technologies for immobilization of enzymes and surface analysis techniques for immobilized enzymes, Biotechnol. Biotechnol. Equip. 29 (2015) 205-220. doi:10.1080/13102818.2015.1008192. 